Canadian Studies in Population 43, no. 1-2 (2016): 117-145.

\title{
Developments in Australian migration
}

\author{
David Smith ${ }^{1}$ \\ Dan Payne \\ Mathew Horne \\ Debbie Claridge
}

\begin{abstract}
Against the backdrop of changes in the nature and volume of people movement, migration to Australia has changed substantially in the past decade. Using a diverse range of statistical data and departmental policy information, this paper provides a comprehensive assessment of recent developments, discussing not only changes in the scale and composition of migration to Australia, but also the influence of policy decisions and various departmental programmes on this movement. The paper also examines the dispersal of migrants throughout the country post-arrival and the linkages between temporary and permanent migration, which are a reflection of increased global mobility and changing attitudes to permanent settlement.
\end{abstract}

Keywords: Australia, migration policy, permanent migration, temporary migration, Australian citizenship.

\section{Résumé}

Les changements dans la nature et le volume de mouvements démographiques en toile de fond, la migration vers l'Australie changea considérablement au cours des derniers dix ans. Au moyen de données statistiques variées et de l'information sur les politiques du département, cet article fournit une évaluation complète des derniers développements en examinant les changements dans l'échelle et la composition de la migration en Australie ainsi que l'influence des décisions stratégiques et des divers programmes départementaux sur ce mouvement. L'article examine la dispersion des migrants à travers le pays après leur arrivée ainsi que les liens entre la migration temporaire et permanente reflétant une plus grande mobilité mondiale et de nouvelles attitudes à l'égard de l'établissement permanent.

Mots-clés : Australie, politique de migration, migration permanente, migration temporaire, la citoyenneté australienne.

\section{Introduction}

Australia is a country built on migration. At the time of the 2011 Census, more than one-quarter of the population was born overseas-more than double the rate at the end of the Second World War (Figure 1). Another one in five Australians has an overseas-born parent (ABS 2011). Collectively, this means that in the Australia of today, almost half of the population has a direct migrant connection. In addition, there are more than one million people temporarily in Australia at any one time (DIAC 2013b).

1. David Smith, Director, Economic Analysis Unit, Policy Research and Statistics Branch, Strategic Policy and Planning Division, Policy Group, Australian Government Department of Immigration and Border Protection, PO Box 25, Belconnen, ACT 2616, Australia, e-mail: david.smith@border.gov.au; and Dan Payne, Mathew Horne, and Debbie Claridge, all of the Australian Government Department of Immigration and Border Protection. 


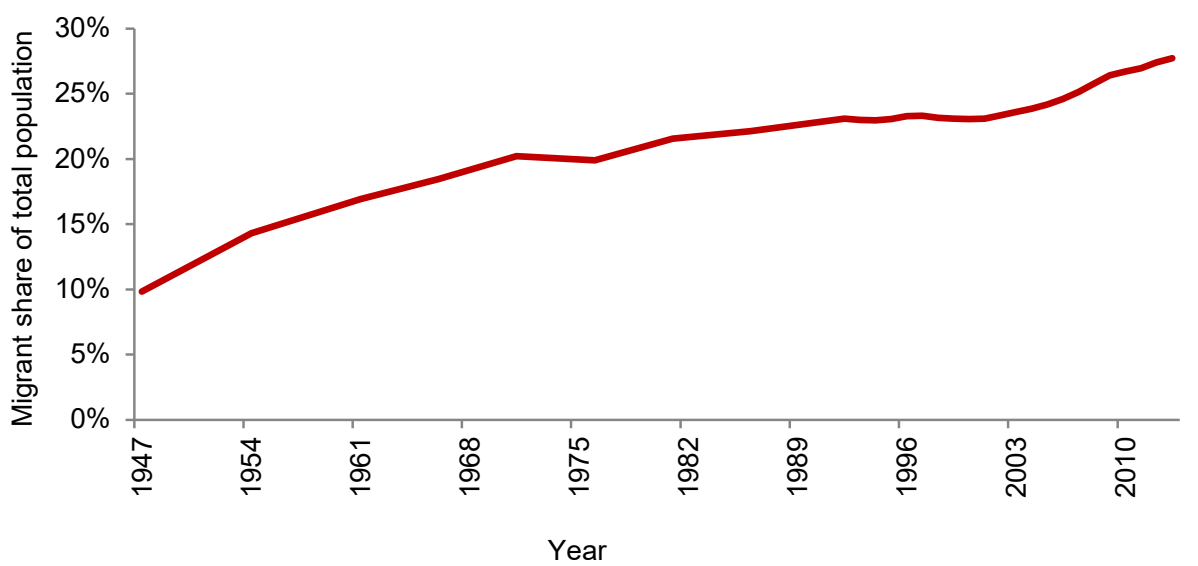

Figure 1. Growth in Australia's migrant population share.

What is even more remarkable is that this impact on Australian society has occurred in less than a lifetime. At the end of the Second World War and on the eve of its first formal migration programme, Australia was an Anglo-Celtic society of just seven million. Since then, Australia has received almost eight million new migrants into the country, including 825,000 former refugees fleeing conflict and persecution (DIBP 2014e). A measurable impact of this transformation is that between 1947 and 1999, the share of the population that identified as Anglo-Celtic fell steadily, from 89.9 per cent to 69.9 per cent (Price 1999).

The importance of migration has not abated over this period. In fact, one could argue that it is more important than ever, as the country grapples with the challenges of an ageing population against a backdrop of below-replacement fertility. This is why we have a permanent migration programme running at record levels, a heavy emphasis on skilled migration and are increasingly open to temporary migration.

Despite these seismic shifts, Australian attitudes towards migration are generally positive. Results from the 2013 Scanlon Survey of Social Cohesion show strong levels of support for multiculturalism with 84 per cent of respondents agreeing with the statement that multiculturalism has been good for Australia, 75 per cent saying it benefits the economic development of Australia and 60 per cent saying that multiculturalism strengthens the Australian way of life (Markus 2013).

If this paper was being written in 1984, we could be far more definitive about this subject. Thirty years ago almost all migrants coming to Australia would arrive with the intention of settling permanently. The handful of students, skilled workers and working holiday makers that were in Australia on a temporary basis would first have to return overseas if they wanted to apply for permanent settlement. Now, in an era of increased international mobility, brought about by improvements in communication, lower airfares and the emergence of a global workforce, the world is getting much smaller and traditional migration paradigms are less applicable.

Compared to earlier decades, the contemporary setting is more likely to involve migrants who first arrive on a temporary visa, and then subsequently make a decision to apply for permanent residence onshore. In today's more mobile world, this decision-making process may take several years, as people progress from one temporary visa to another and venture to different parts of the world along the way. The concept of permanence is shifting as well, with many permanent residents eventually leaving Australia not because they are dissatisfied, but because they want to take advantage of opportunities that are increasingly accessible elsewhere in the world.

In this paper, we look at the changing face of migration in Australia, with a particular focus on recent developments. In doing so, we will be discussing changes in the scale and composition of tempor- 
ary and permanent migration into Australia, the linkages between temporary and permanent migration, the dispersal of migrants throughout the country and the effect of policy-decisions on migration.

\section{The two sides of permanent migration to Australia: Immigrants and refugees}

When we think of permanent migration, there are two main elements to consider; each of which is important in its own way. In terms of numbers and impacts on wider Australian society, the most substantive of these is Australia's Migration Programme. This incorporates both skilled and family reunion migration, and is the main pathway to permanent residence for around 190,000 migrants each year (DIBP 2014g).

The other side to permanent migration is Australia's Humanitarian Programme. Although only a fraction of the size of the Migration Programme, the policy's complexity and extent of international collaboration and involvement are significant. The issues surrounding both of these programmes are quite different, and as such, it is appropriate that they are discussed separately.

Before doing so, it's worth noting that the free movement of New Zealanders into Australia via the Trans-Tasman Travel Arrangement could also be considered as a form of permanent migration. This is because New Zealand citizens who arrive in Australia are able to live and work in Australia indefinitely, provided that they satisfy health and character requirements. However, the situation differs for those who arrived before and after February 2001, the time that the Australian Government introduced new residence and citizenship rules for New Zealand citizens. These rules work as follows:

1. Those who arrived before February 2001 are automatically eligible for social security payments and Australian citizenship;

2. Those arriving after February 2001 need to apply for a permanent residence visa if they wish to get access to the full range of social security payments and become eligible for Australian citizenship.

Under these arrangements, the reality for most New Zealanders living in Australia is that they are neither in a relationship with an Australian resident (meaning that they are unable to apply for a family reunion visa), nor do they necessarily have the skills and experience needed to apply for a skilled visa. This means that the pathway to citizenship is essentially blocked.

In this light, our focus returns to Australia's Migration Programme and the Humanitarian Programme.

\section{Australia's Migration Programme-the main pathway to settlement}

Australia's permanent migration programme supports two important objectives:

1. It contributes to economic and labour force growth through the delivery of skilled migrants;

2. It enables the reunion of Australians with close family members.

These objectives are administered through the two separate streams of immigrants, namely, the skill stream and the family stream. As the name suggests, the skill stream provides a migration pathway for persons with certain skills to contribute to Australia's economy, whereas the family stream helps Australians reunite with their close family members overseas. A further stream, known as the special eligibility stream, is much smaller in terms of the number of places. Its role is to allow for people who previously held permanent residence to re-enter the country permanently, so long as they have maintained close ties with Australia. 
The annual Migration Programme is announced by the Government as part of the federal budget in May each year. In developing the programme, options are provided surrounding the size- - how many places overall—and the composition—what categories of migrants make up those places. Determining this make-up relies on many factors, including economic and demographic indicators, estimates of demand for skilled labour from a range of sources, and long-term labour force growth estimates.

\section{2a - Total Visa Growth}



Programme Year

$\square$ Skill Stream Total — $\quad$ Proportion of Migration Programme

\section{2b - Primary Visa Holder Growth}

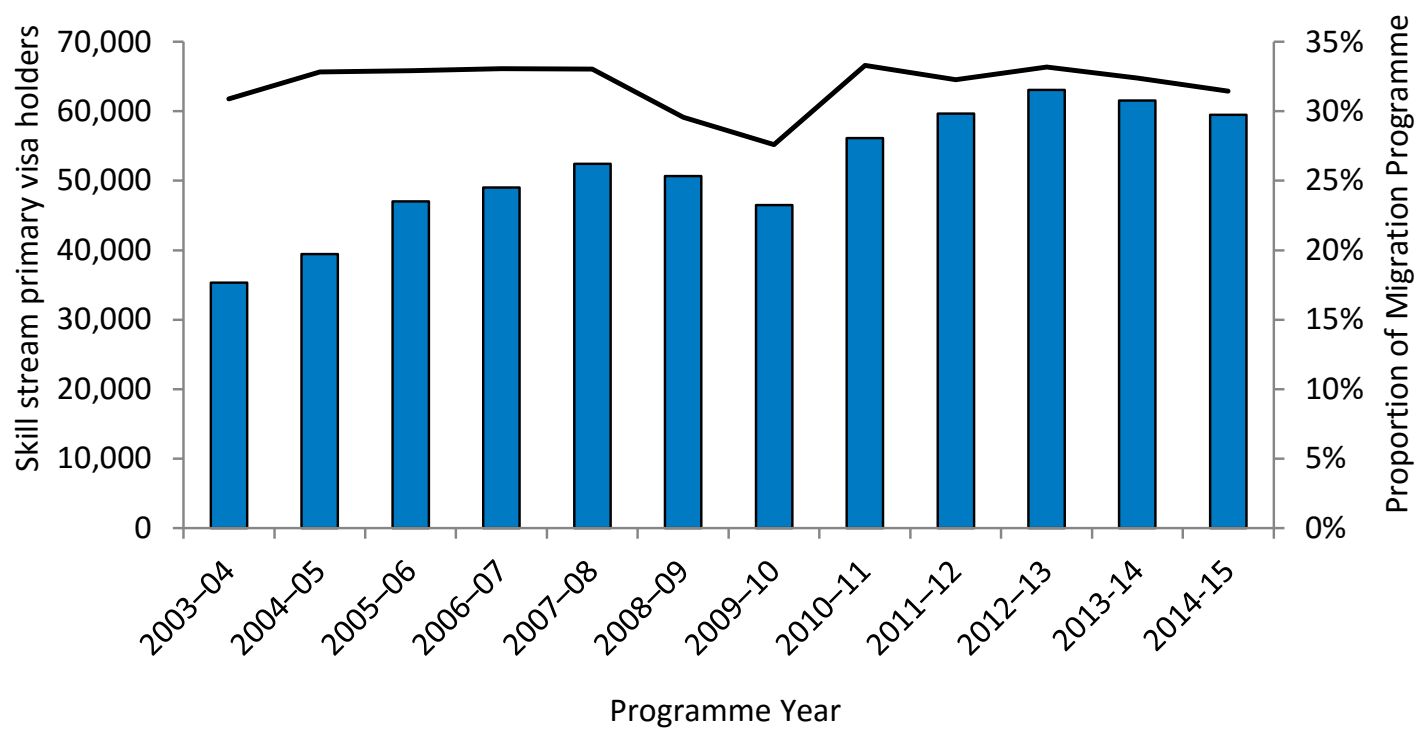

Skill Stream Primary — Proportion of Migration Programme

Figure 2a and 2b. Growth of the Skill stream, 2003-04 to 2014-15.

Source: Department of Immigration and Border Protection, Migration Programme Outcome Data. 
In addition to this, the Government consults widely with key stakeholders, including government agencies as well as representatives from the community, business, and academia. The product of these deliberations is planning levels for various visa categories within the three streams of the Migration Programme.

Planning levels are ceilings, not targets. The Department carefully manages and reviews these levels throughout the year, to ensure the responsiveness of the programme to Australia's economic and social needs. For example, in March 2009 the skilled component of the programme was reduced by 14 per cent, in response to the weaker labour market conditions that arose from the global financial crisis (DIAC 2009: 29).

\section{The Skill stream}

The Skill stream accounts for more than two-thirds of Australia's annual Migration Programme, and has more than tripled in size since the year 2000 (DIBP 2014g). In delivering ever larger skilled programmes, successive governments have made the case that skilled migration enhances workforce participation and results in stronger productivity, along with greater entrepreneurism and connectedness with the rest of the world.

In analysing this growth, it should be understood that official figures include the entire migrating unit- that is, the Primary Applicant as well as their dependents (children included). Therefore, in order to get a more accurate assessment, Figures $2 \mathrm{a}$ and $2 \mathrm{~b}$ present skilled migration growth in two ways: first in terms of all migrants, and then in terms of the Primary Applicant only-that is, the person selected

Figure 3. Components of Australia's Skill stream, visa places in 2014-15

\begin{tabular}{|c|c|}
\hline \multicolumn{2}{|c|}{ Skill stream-127,774 visa places } \\
\hline Points-Tested Skilled Migration & Permanent Employer-Sponsored \\
\hline 72,840 places & 48,250 places \\
\hline Applicants are not sponsored by an employer but & Applicants must be sponsored by an Australian \\
\hline must: be invited to apply; be under 50 years of age; & employer to fill a genuine vacancy in the employer's \\
\hline have competent English; have relevant skills and & business. The programme caters to migrants in \\
\hline qualifications for an occupation on a designated & Australia on a Temporary Work (Skilled) visa (sub- \\
\hline list; and have their skills assessed by the relevant & class 457), those applying from outside Australia or \\
\hline assessing authority. They must also pass a points & already in Australia on a temporary visa other than the \\
\hline test that awards higher points to prospective & subclass 457 visa programme, and those sponsored \\
\hline migrants with certain skills and characteristics. & through a tailored and negotiated Labour Agreement. \\
\hline Visa categories: & Visa categories: \\
\hline Independent- & Employer Nomination Scheme (ENS)_- \\
\hline 43,990 places & 35,867 places \\
\hline State/Territory Sponsored- & Regional Sponsored Migration Scheme \\
\hline 26,050 places & (RSMS)-12,380 places \\
\hline Skilled Regional-2,800 places & Labour Agreements $-<5$ places $^{\mathrm{a}}$ \\
\hline
\end{tabular}

Business Innovation and Investment 6,484 places

Applicants must have a demonstrated history of success in innovation and business and want to own and manage a new or existing business in Australia, or maintain business and investment activity in Australia after making an investment in Australia. Once the initial stage provisional visa requirements are fulfilled, the migrant can apply for a second-stage permanent visa.

\section{Distinguished Talent} 200 places

Applicants must have special or unique talents of benefit to Australia. This visa is typically granted to individuals internationally recognised for exceptional and outstanding achievement in a profession, the arts, sport, or research and academia.

Source: Migration Reporting, Department of Immigration and Border Protection.

${ }^{\text {a} F r o m ~} 1$ July 2012, Labour Agreement visas were replaced with new arrangements made available in the ENS and the RSMS. 
for skilled migration. As can be seen from these figures, the number of migrants selected on the basis of their skills accounts for about half the total number of skilled visas issued, and over the past decade, skilled migration's share of the total programme has remained about the same. This is a departure from earlier trends: prior to 1996, skilled visas accounted for less than half of the total Migration Programme.

To investigate skilled migration more deeply, it is first important to understand that it is made up of four components, each fulfilling a different objective. As shown in Figure 3, the largest of these components is Points Tested Skilled Migration, which comprised 56 per cent of the Skill stream in 2014-15. This is followed by the Employer Sponsored and the Business Innovation and Investment categories, accounting for 37 per cent and 5 per cent, respectively. Distinguished Talent is the smallest component, representing only 0.2 per cent of the Skill stream in 2014-15.

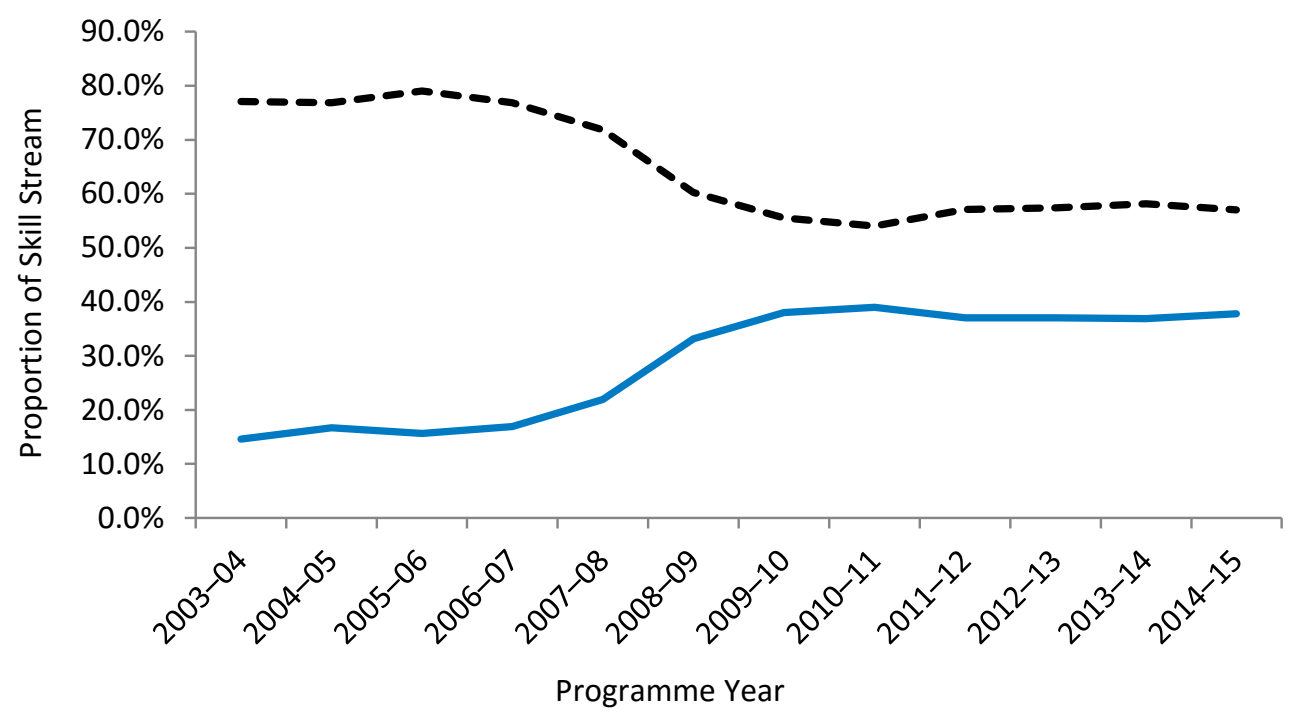

- Points-tested proportion of Skill Stream Sponsored proportion of Skill Stream

Figure 4. Volume of points-tested and demand-driven visas, 2003-04 to 2014-15.

Source: Department of Immigration and Border Protection, Migration Programme Outcome Data.

While points-tested migration is the largest component of the Skill stream, its share has decreased in recent years (Figure 4). This has happened as governments have favoured demand-driven migration policies that can meet the immediate needs of business, and have instructed that applications for employer sponsorship are to be given the highest processing priority. In contrast, pointstested migration is designed to recognize a migrant's human capital and employment potential, and is therefore more targeted at meeting Australia's longer-term skills needs.

There have also been substantial changes to the way the points test operates over the past decade (Cully 2011). In 2007 there was an increase in the minimum English requirements, and the test itself allocated a greater share of points to English ability. This was in response to concerns about inadequate levels of English among some skilled migrants, and the strong association between English proficiency and labour market performance.

In early 2010, the Migration Occupations in Demand List (MODL), a list of almost one hundred occupations that could contribute up to one-sixth of the points test pass-mark, was revoked. This was because it was not reflecting genuine labour shortages, and many occupations on the list were associated with low-value, easily acquired qualifications. Essentially, the MODL was introducing distortions to the skilled migration caseload; for example, colleges were being established that offered 
low-quality (but often high-cost) courses to international students (e.g., hairdressing and cookery) with the sole aim of delivering an easy pathway to skilled migration.

The points test requirements changed again in July 2011 (DIAC 2011a). This time, the changes were more substantive and were intended to remove inequities which had favoured migrants aged under 30, did not award points for qualifications obtained outside of Australia, and undervalued overseas work experience. Collectively, these factors had worked against older, more experienced migrants applying offshore for skilled migration.

Furthermore, with the growing emphasis on demand-driven migration and the consequent decline in the number of points-tested visas that were issued, the test also sought to raise the overall standard of applications. This was done through increased recognition of higher qualifications, attaching greater weight to English ability, and awarding maximum points for those with a superior level of English or above. It was also accompanied by a much shorter Skilled Occupational List (SOL), which went from 400 occupations to under 190. The SOL, which is used to prescribe the range of eligible occupations for skilled migration, had been allowed to grow over the years, and like the MODL, it did not necessarily reflect the skill needs of employers. As well as being shorter and more targeted, the government made the commitment to have the composition of the SOL reviewed annually.

To facilitate a pathway to permanent residence for international students, the government introduced a temporary visa known as the Skilled Graduate visa in September 2007 (DIAC 2009: 12-13). This visa was valid for 18 months, and gave former students who did not meet the criteria for pointstested migration additional time to improve their skilled migration prospects by undertaking further study, seeking employer sponsorship, or improving their level of English. Alternatively, they could use the additional time they had in Australia to gain work experience and then return to their home country.

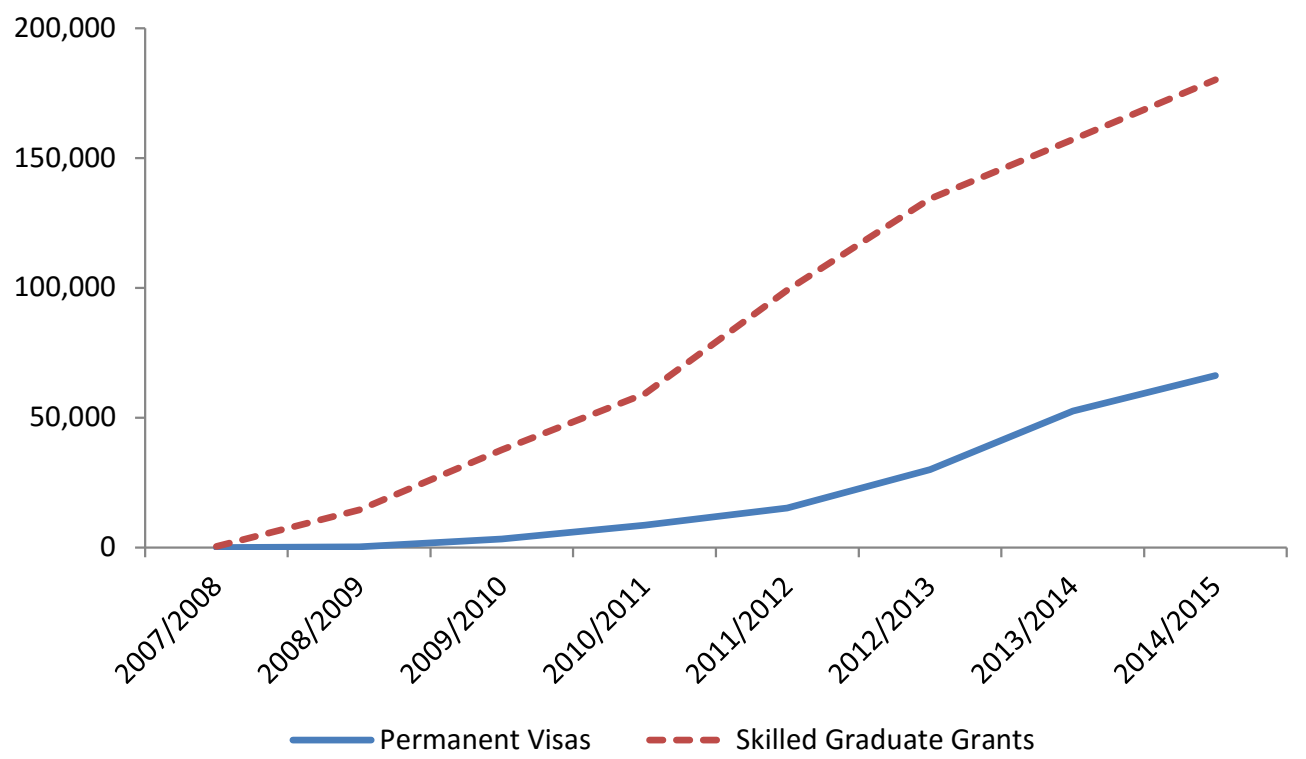

Figure 5. Cumulative totals of Skilled Graduate visas issued and subsequent permanent visa grants, 2007-08 to 2014-15.

Source: Department of Immigration and Border Protection Migration Programme Outcome Data.

Data from the Department indicates that from 2007-08 to 2014-15, just over 180,000 Skilled Graduate visas were granted to former students. Among this cohort, just over 66,000 had gone on to secure permanent residence by the end of $2014-15,5,600$ of whom received a visa through the family reunion programme. Figure 5 shows, by the use of cumulative totals, the time lag between a 
Skilled Graduate visa and subsequent grant of a permanent visa. ${ }^{2}$

This particular visa was amended in early 2013, and was renamed the Temporary Graduate visa, which is valid for up to four years but no longer provides a direct application pathway to permanent skilled migration. It is now a temporary visa designed to provide graduates with an opportunity to obtain work experience, helping to make them more employable upon their return to their home country.

The visa has two streams: (1) The graduate work stream is for eligible international students who graduate with skills and qualifications that relate to an occupation on the skilled occupations list; and (2) The post-study work stream caters to international students who graduate with a higher education degree from an Australian education provider regardless of their field of study.

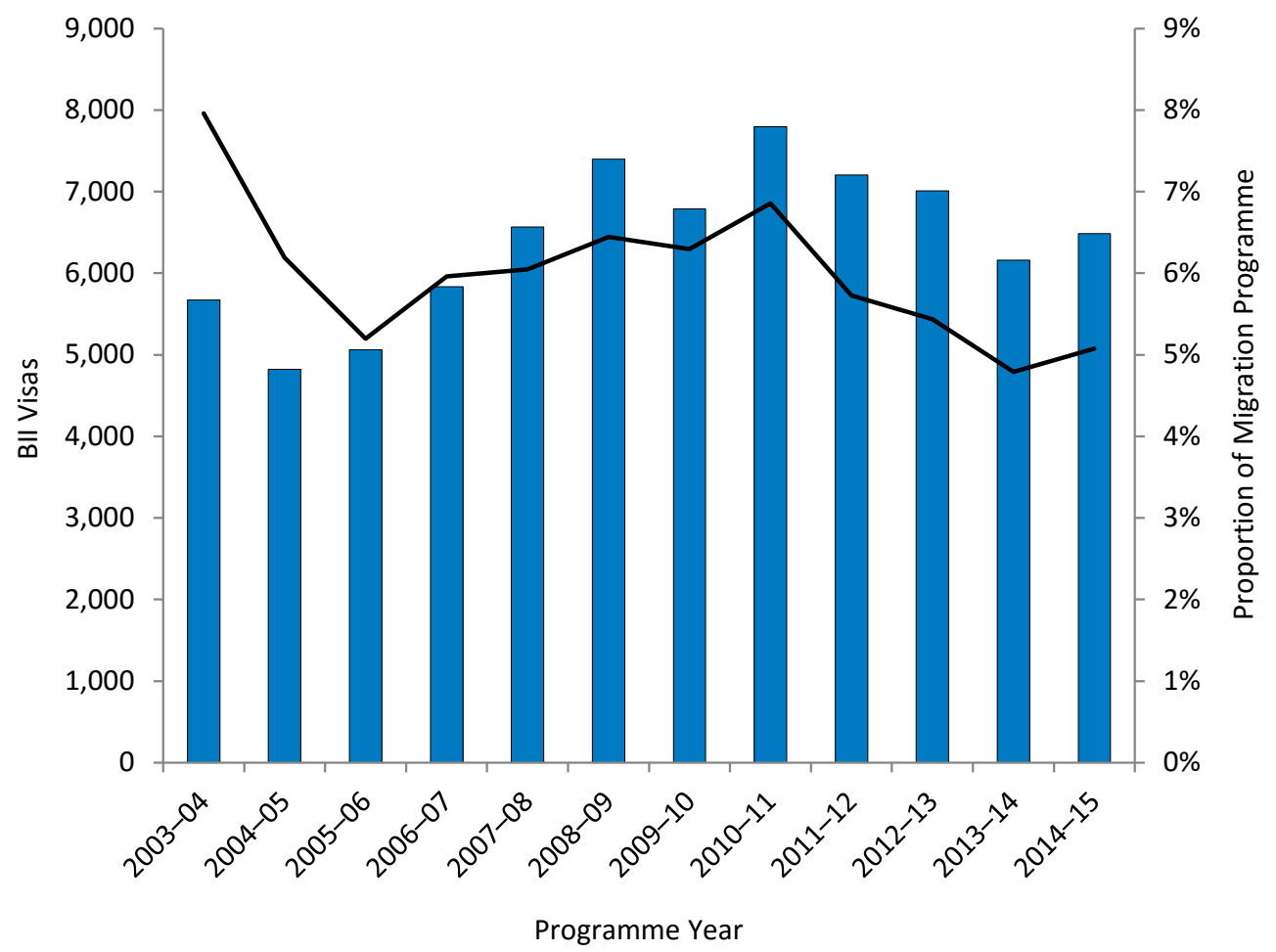

Business Innovation and Investment Visas _ _ Proportion of Migration Programme

Figure 6. Business visas granted, 2003-04 to 2014-15.

Source: Department of Immigration and Border Protection, Migration Programme Outcome Data.

Over the course of the past decade, the number of business migrants to Australia has varied little, ranging between 5,000 and 8,000 grants (Figure 6). However, on the back of the country's strong economic resilience during the global financial crisis of 2008, Australia was in a position to be more discriminating about the migrants selected through this programme. Following a comprehensive review, the Business Skills Programme was replaced by the Business Innovation and Investment Programme (BIIP) in July 2012. By utilizing a points test, this new programme is designed to encourage a greater level of entrepreneurism and investment among business migrants, and to foster innovation (DIAC 2012).

2. While these data could be used to infer that just over one-third of Skilled Graduates went on to secure permanent residence, it should be remembered that there would be a significant lag between the issuing of a Skilled Graduate visa and the subsequent issuing of a permanent visa. As a result, the proportion of visa holders who were successful in obtaining permanent residence would be somewhat higher. 
One important aspect of this new Programme is the Significant Investor visa. This particular visa is targeted at individuals willing to invest at least $\$ 5$ million into the Australian economy. To encourage this investment, and in acknowledgement of their greater mobility, experience, and access to business networks, this visa offers some concessions, such as a reduced residency period and no upper age limit.

Further changes to the SIV programme were introduced on 1 July 2015, including: (1) greater oversight of 'complying investment' policy to ensure investment settings reflect national priorities; (2) creation of new residency requirements, to encourage the families of high net-worth individuals to settle longer-term in Australia. Additionally, there was the introduction of a Premium Investor visa (PIV) requiring a \$15 million complying investment and offering eligibility for permanent residence after 12 months.



Offshore

Onshore

- Onshore proportion

Figure 7. Onshore and offshore Skilled Visa grants 2003-04 to 2014-15.

Source: Department of Immigration and Border Protection, Migration Programme Outcome Data.

\section{Temporary migration issues}

\section{Onshore migration}

Reflecting the changing nature of migration, an increasing share of the permanent skilled migrant cohort is made up of people who are already in Australia on a temporary visa. The past decade has seen the onshore proportion increase from 32.7 per cent to 55.4 per cent in 2014-15 (Figure 7). Delving a little deeper, in 2014-15 more than 32 per cent of skilled visas issued onshore were to people who were on a student visa or who had moved from a student visa to some form of skilled graduate visa. Another 61 per cent were people on long-term temporary skilled visas.

One positive consequence of growth in the onshore proportion of skilled migrants is that these people have already grown accustomed to life in Australia, and their decision to stay or go is an informed one. A recent departmental report, based on a survey of more than 3,000 subclass 457 visa holders, shows that around three-quarters of them intended to seek permanent residence in Australia, which is reflective of the fact that more than 90 per cent indicated they were settling well 
into Australian society (DIBP 2014d). ${ }^{3}$ Among those visa holders who wanted to leave Australia, the most common reasons cited were the high cost of living, homesickness, and their partner wanting to return to their home country.

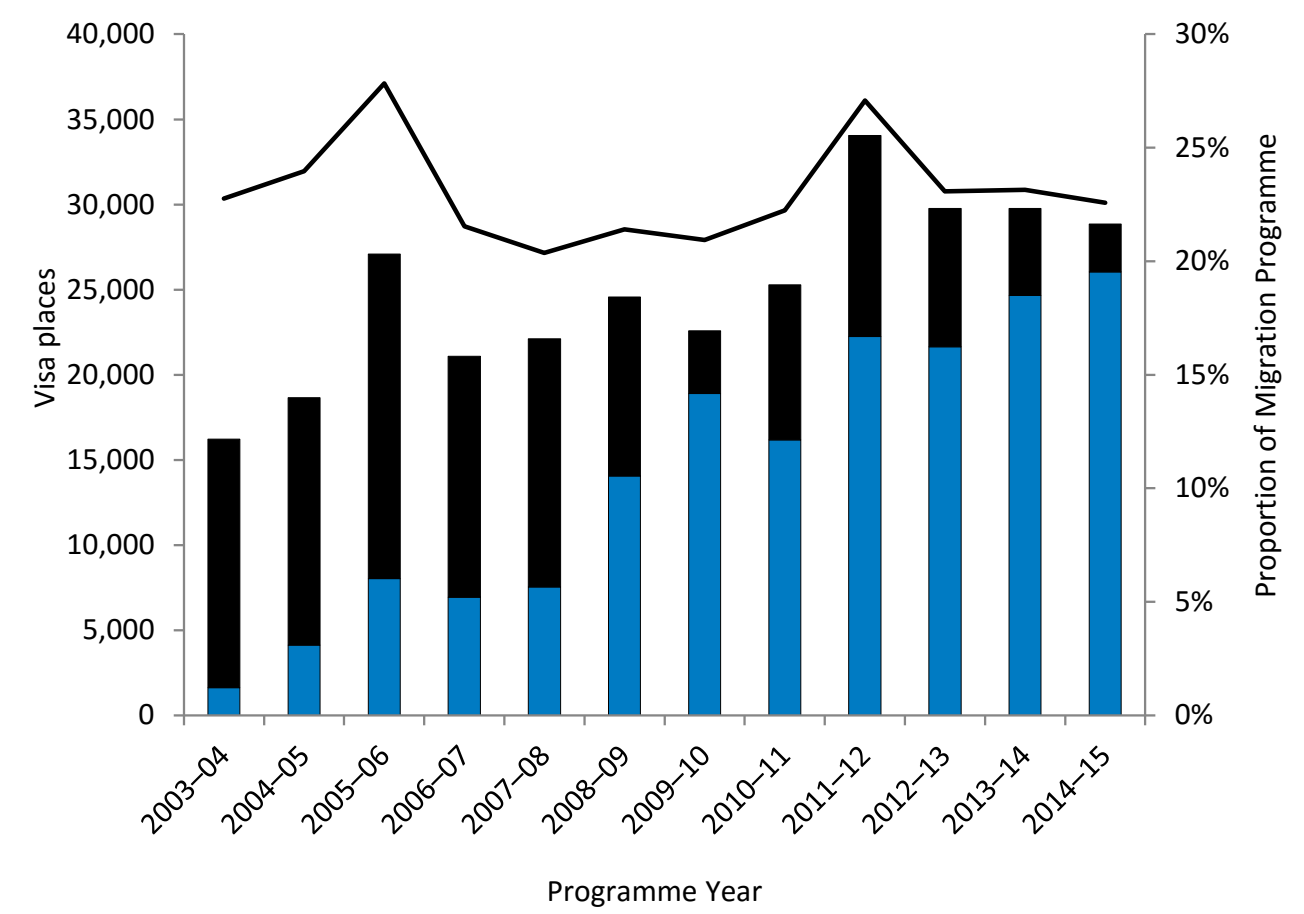

$\square$ State and Territory Sponsored

Skilled Regional _ Proportion of Migration Programme

Figure 8. State/Territory Sponsored and Skilled Regional Visa schemes to promote migration to specific state or territory and regional areas in Australia.

Source: Department of Immigration and Border Protection, Migration Programme Outcome Data.

\section{Regional migration}

Over the past decade, there has been an absolute growth in schemes that promote migration to specific jurisdictions, or to regional and low population growth areas in Australia (Figure 8).

They also include flexible criteria that recognise the special circumstances of rural and regional areas, and aim to attract young, skilled, English-speaking migrants to areas of Australia where they are most needed. Skilled migration visas that are sponsored by regional employers or nominated by state and territory governments also receive priority processing, enabling them to influence the number and profile of skilled migrants settling in their areas in line with their skill needs and development objectives (DIBP 2014f).

State Nominated and Territory Nominated visas are a points-tested visa introduced in 1999, intended to give governments in each jurisdiction greater flexibility in addressing specific skill shortages and local labour market needs. This is a significant issue for Australia, as the strength of labour markets and the demand for particular occupations varies widely across the country. Compared with more conventional points-tested visas, these visas provide separate occupation lists for each jurisdic-

3. The survey asked people to use a score of zero to ten to indicate how well they were settling in Australia; more than 90 per cent provided a score of seven or higher. 
tion, which can reflect local needs. Points are also awarded for state or territory nominations, and applications are processed as a higher priority.

Skilled Regional Sponsored visas are points-tested visas that enable a participating state or territory government to nominate, or an eligible relative to sponsor, a skilled migrant. Like the State and Territory Nominated visas, applicants for these particular visas are awarded points for sponsorship. It is also important to note that these visas are first issued on a provisional basis, and provided they meet the residency requirements, visa holders are eligible to apply for a permanent visa. ${ }^{4}$

Regional Sponsored migration is a form of employer sponsorship designed to address skilled shortages in Australia's regions. Under current arrangements, a sponsoring employer's workplace can be located anywhere in Australia, except for Melbourne, the Brisbane-Gold Coast region, and the Newcastle-Sydney-Wollongong conurbation. Compared with the standard form of employer sponsorship, salary levels are generally lower, given that they need only satisfy minimum wage laws, and the range of eligible occupations is greater. ${ }^{5}$ Both forms of employer sponsorship are founded on the principle that the job being filled could not be undertaken by an Australian worker and that the migrant being sponsored is being paid at market rates - a deliberate strategy to ensure that there is no undercutting of wages and conditions or exploitation of migrant workers.

More recently, designated area migration agreements (DAMAs) ${ }^{6}$ have been introduced. These allow businesses from anywhere within Australia that are experiencing labour shortages to sponsor skilled and semi-skilled workers from overseas. DAMAs are built on the principle that Australians are recruited as a first priority and that participating employers develop strategies to facilitate the recruitment and retention of Australian workers (DIBP 2015).

\section{SkillSelect}

This is the Department's online skilled migration system, introduced in July 2012, and designed to give the Australian Government greater control over the composition and quality of the Skilled Migration programme (DIAC 2013a). Migrants interested in points-tested skilled migration or business migration (DIBP 2014a) are now required to submit an online expression of interest in SkillSelect for most of these visas. Those seeking employer sponsorship may still approach an employer directly, or they can submit an expression of interest through SkillSelect to bring themselves to the attention of potential employers.

Compared with the former approach of people submitting an application and waiting for a decision, the advantage of this approach is that it does away with long processing pipelines. The Department has control over when it invites people to apply and the number of invitations that are issued. This ensures that the skilled migrant cohort is not dominated by a small number of occupations, which could potentially crowd out local workers. In addition, ceilings are applied across all occupations.

4. To qualify for a permanency, visa holders nominated by a State or Territory government need to have lived for a minimum of two years outside of the Sydney-Newcastle-Wollongong conurbation, the Brisbane-Gold Coast conurbation, Melbourne, Perth, and the Australian Capital Territory. If sponsored by a relative, the visa holder is eligible if they have lived anywhere outside of Brisbane and the Sydney-Newcastle-Wollongong conurbation.

5. The range of eligible occupations for an RSMS visa extends to any job that requires a minimum of a certificate level III qualification, accompanied by two years of relevant work experience. For an ENS visa, the range of eligible occupations is limited to jobs on the Department's Consolidated Skilled Occupations list.

6. Designated Areas of Australia, http://www.border.gov.au/Trav/Work/Work/Allocation-dates-for-GeneralSkilled-Migration-applications/designated-areas. 
Figure 9. Components of the Family stream, 2014-15

Family stream-61,085 visa places

Partner- $-47,825$ visa places

Applicants must be married, intending to get married (fiancé) or in a de facto relationship (including those in a same-sex relationship) to an eligible Australian resident. Main visa categories:

Prospective marriage-4,745 places

Partner (spouse/de facto)—43,080 places
Child-4,135 visa places

Applicants must be a dependent child of an eligible Australian resident.

Main visa categories:

Child-3,541 places

Adoption-190 places

Orphan Relative-404 places

Parent- 8,675 visa places

Applicant must have a child who is an eligible

Australian resident. To help offset the cost to

Australia of Parent visas, the Contributory Parent

visa costs more, but is generally processed faster.

Main visa categories:

Parent-1,500 places $^{\mathrm{a}}$

Contributory Parent-7,175 places Other Family - 450 visa places

Applicant must be joining their remaining relative (sibling or parent), or an aged relative who depends on an Australian relative for most of their living costs, or a carer needed to look after an Australian relative with a medical condition.

Main visa categories:

Remaining Relative - 76 places

Aged Dependent Relative- $<5$ places Carer-370 places

Source: Migration Reporting, Department of Immigration and Border Protection.

${ }^{\mathrm{a}}$ Closed to new applications on 2 June 2014 and reinstated on 25 September 2014.

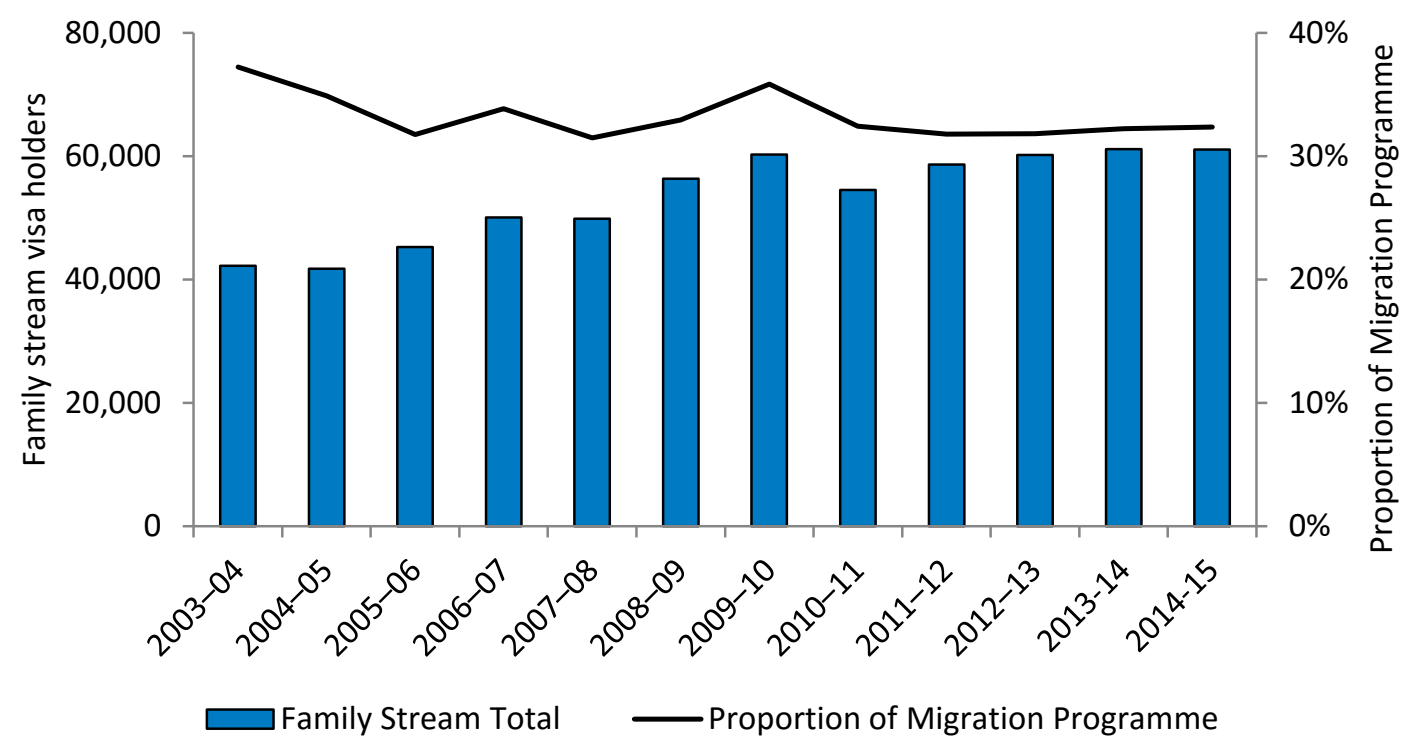

Figure 10. Growth in the Family stream, 2003-04 to 2014-15.

Source: Department of Immigration and Border Protection, Migration Programme Outcome Data.

\section{Family stream}

The Family stream of the Migration Programme enables the entry of close family members of: Australian citizens, Australian permanent residents, and eligible New Zealand citizens. It focuses on reuniting the affianced, partners, and dependent children, and also provides the opportunity for other family members, such as parents, aged dependent relatives, carers, and last remaining relatives, to join their family in Australia. Australia's Family stream is comprised of four components (Figure 9). The 
largest of these is the Partner category which accounted for more than three-quarters of all family migration in 2012-13. This is followed by Parent and Child categories, accounting for 14 per cent and 6 per cent, respectively. The remaining components are even smaller, and in 2014-15 collectively represented only 2.1 per cent of the Family stream.

The Child category was a component of the Family stream of the annual managed migration programme until 2015/2016. In support of the Prime Minister's Inter-country Adoption agenda, from 2015 to 2016 Child category visas were removed from the managed migration programme. This removal was to transition child visas to a demand-driven model.

When examined over the past decade, the size of the Family Programme has increased by around 46 per cent. However, successive governments' increased emphasis on skilled migration has meant that the pace of growth has not kept up with the rest of the Migration Programme. In 2004-05, 35 per cent of all Migration Programme visas were issued through the Family stream (Figure 10);

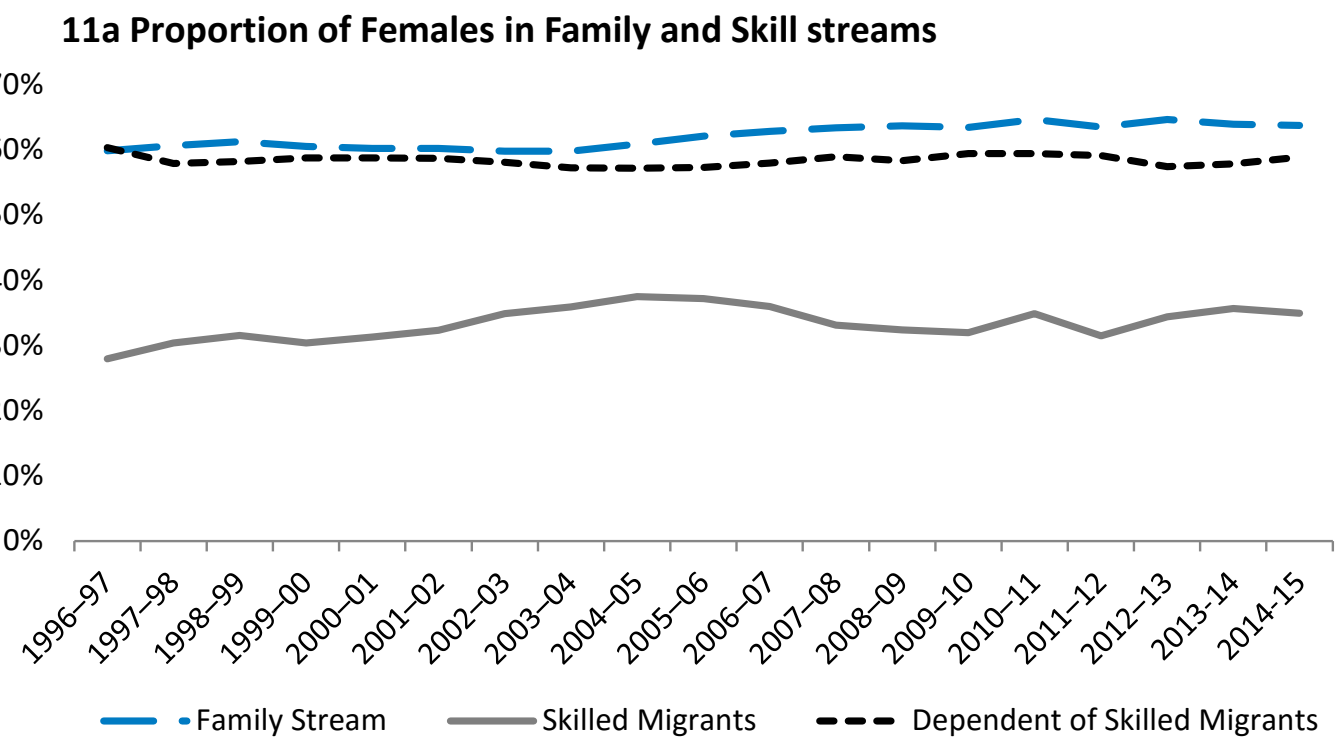

\section{1b Age Distribution of Family and Skill stream}

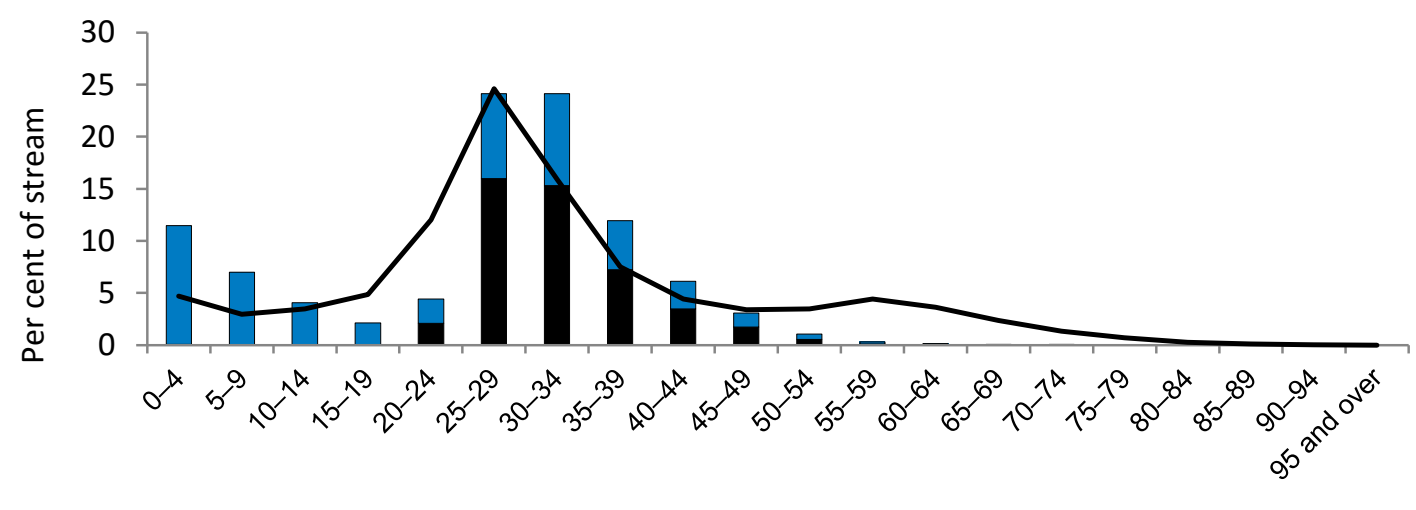

Skilled Migrants

Dependents of Skilled Migrants Family Programme

Figures 11a and 11b. Demographics of the Family and Skill streams.

Source: Department of Immigration and Border Protection, Migration Programme Outcome Data. 
ten years later, this figure had fallen to 32 per cent. $^{7}$ There are a growing number of international students, working holidaymakers, and migrants on temporary skilled visas who are applying through the Family stream. In 2014-15, more than one-fifth of all family visas went to these temporary migrants.

A consequence of the way the Family Reunion Programme is structured is that it does deliver some important demographic dividends. As shown in Figure 11a, a Migration Programme entirely made up of primary applicant skilled migrants would have males outnumbering females by about two to one. Family migration, which is about two-thirds female, plus the migration of dependents of the skilled migrants (which is around sixty per cent female), helps to offset this gender imbalance.

Figure 11b shows that skilled migrants are concentrated in a narrow age range between 25 and 34 years of age. By comparison, the dependents of skilled migrants are mainly young children. Collectively, the skill and family streams are therefore delivering migrants who are in the prime of their working life, as well as a substantial cohort of younger people who represent the workforce of the future.

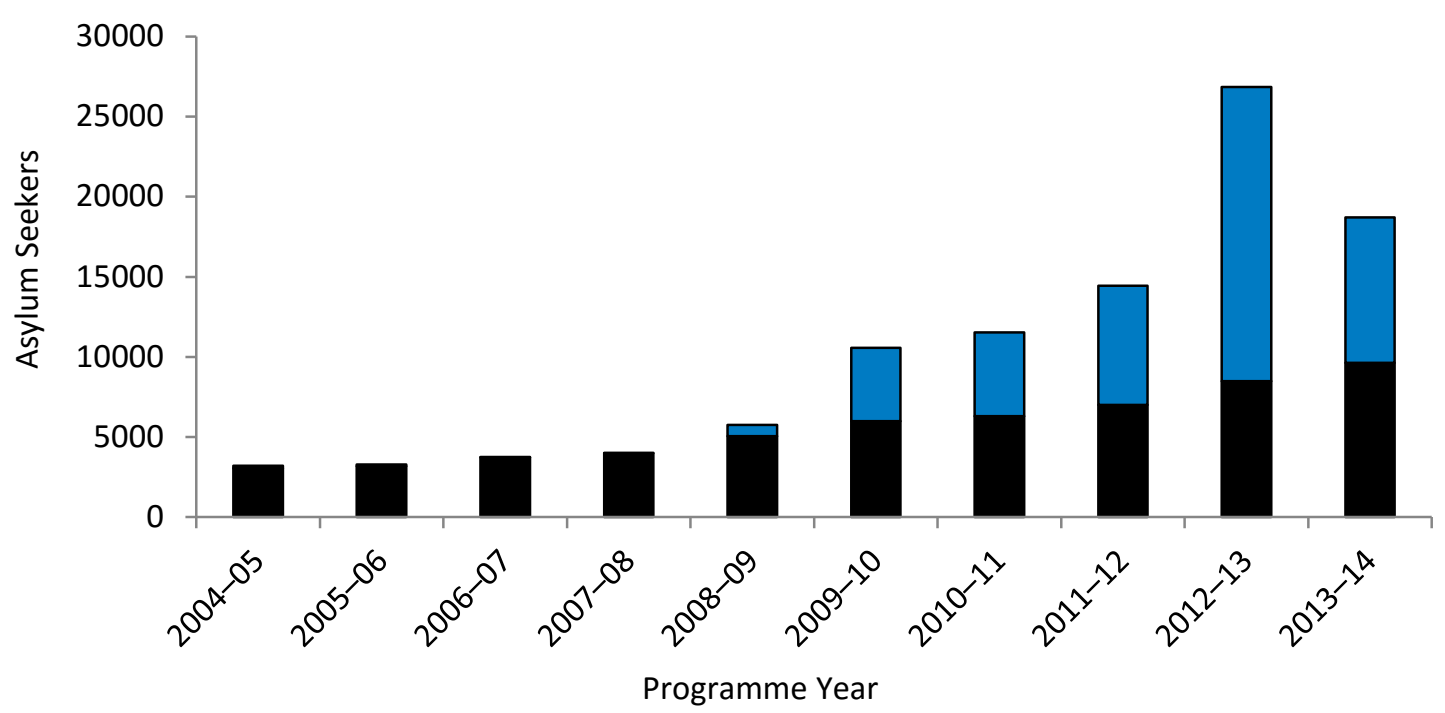

Non-IMA PV applications lodged

$\square$ IMA requests received

Figure 12. Onshore asylum seekers, 2003-04 to 2013-14.

Source: Department of Immigration and Border Protection systems.

Note: Refugee status determination requests from 2008-09 onwards are counted as people screened into a determination process for IMAs. Figures are as officially revised at the end of 2013-14, and therefore may differ from statistics previously published.

\section{The Humanitarian Programme}

\section{Programme Structure}

Australia's Humanitarian Programme has an offshore resettlement component and an onshore protection component. Within the offshore component there are two categories. The Refugee category is for people who are subject to persecution in their home country, most of whom are identified by the UNHCR as being in need of resettlement and referred to Australia for consideration. Within the Refu-

7. Planning levels for 2013-14 and 2014-15 see the Family stream continuing to account for 32 per cent of the total Migration Programme, which remains at 190,000 places. 
gee category is the Woman at Risk visa subclass, for women who don't have the protection of a male relative and are in danger of being victimized, harassed, or seriously abused because of their gender.

The Special Humanitarian category is for people outside their home country who are subject to substantial discrimination, amounting to gross violation of their human rights. Applicants for Special Humanitarian visas must be proposed for resettlement by an Australian citizen, permanent resident, or organisation that can support them through the settlement process.

The onshore protection component is for people seeking asylum from within Australia. It consists of people who arrive in Australia on a valid visa and subsequently seek asylum, and those who entered Australia illegally by boat (illegal maritime arrivals).

For most of the past decade, the size of Australia's Humanitarian Programme has varied little; aside from a spike of 20,000 places in 2012-13 it has stayed within a narrow range of between 13,000 and 14,000 people per annum. This stability does, however, mask a substantial shift in the balance between offshore resettlement and onshore protection over this period. As seen from Figure 12, the number of people seeking asylum onshore between 2004-05 and 2013-14 has increased from 3,209 to 18,718 per year, with a peak of 26,427 in 2012-13. This was mostly driven by an increase in the number of Illegal Maritime Arrivals (IMAs), from just 21 IMAs in 2007-08 to over 18,000 in 2013-14. With the size of the Humanitarian Programme remaining fairly uniform over this period, this unregulated movement of people had a severe impact on the Department's capacity to provide places for offshore resettlement, and contributed to a sharp decrease in the Special Humanitarian Programme, which fell from almost 9,000 in 2003-04 to 503 in 2012-13. In September 2015, the Australian Government announced that a further 12,000 refugee places would be made available in the 2015-16 programme, as a result of the humanitarian crisis in Syria and Iraq. This increased intake for 2015-16 is on top of the planned increase of 7,500 places over the next three years (Media Release, Dutton 2015).

Associated with the surge in a period of illegal maritime arrivals was a large loss of life at sea. This very difficult policy environment set the scene for a review of the asylum seeker policy by an independent expert panel, ${ }^{8}$ commissioned by the former Federal Government between 2010 and 2013. The ensuing Report of the Expert Panel on Asylum Seekers, released in August 2012, incorporated a range of recommendations to better manage the asylum seeker situation, and to actively discourage people from undertaking hazardous sea journeys to Australia (Houston et al. 2012). The recommendations included:

1. Increased co-operation with Malaysian and Indonesian governments to prevent the transit of potential asylum seekers.

2. Expanding regional processing arrangements to Papua New Guinea and Nauru. The full impact of this recommendation occurred over a twelve-month period. Asylum seekers who entered Australia on or after 13 August 2012 were liable for transfer to a regional processing country (PNG or Nauru) to have their asylum claim assessed. From 19 July 2013, these arrangements were modified so that persons assessed to be refugees in a regional processing country would be resettled in that country or another third country, and would not be resettled in Australia.

3. Placing limitations on family reunions, so that asylum seekers granted protection could no longer use the Special Humanitarian Programme to fast-track the sponsorship of other family members.

8. The expert panel that led the review comprised former Chief of Defence Angus Houston, refugee advocate Paris Aristotle, and the former Foreign Affairs Secretary, Michael L'estrange. The then-Prime Minister, Julia Gillard (24 June 2010-27 June 2013), appointed the expert panel in June 2012, to examine asylum seeker policy and prepare a report recommending a solution for the Government's consideration. 
4. Increasing the 2012-13 Humanitarian Programme to 20,000 places, which included a minimum of 12,000 places for the Refugee category.

5. Removing economic incentives. IMAs who arrived in Australia before August 2012, and those already living in the Australian community, had the right to work and had access to government benefits. Those arriving between August 2012 and July 2013 no longer had work rights and were provided with a reduced level of government benefits.

Following the election of a new government in September 2013, Operation Sovereign Borders was implemented. This border security operation is designed to deter and disrupt people-smuggling activities, detect and intercept illegal vessels, and detain Illegal Maritime Arrivals at regional processing centres so that their asylum claims can be assessed (Customs 2014).

As a way of deterring IMAs and disrupting the activities of people smugglers, these measures-including other changes to the onshore protection component of Australia's Humanitarian Programmehave been highly effective. Based on the evidence to date, what has been particularly effective is removal of the permanent visa pathways and ongoing activities involved with Operation Sovereign Borders. These measures have led to a dramatic decline in the number of asylum seekers arriving in Australia by boat, with recent monthly data indicating that only a handful of IMAs have arrived in $2014 .{ }^{9}$ This is in stark contrast to the thousands of monthly arrivals occurring in early to mid-2013.

\section{Changing composition of the Humanitarian Programme}

The Humanitarian Programme is designed to be flexible and responsive to emerging and ongoing global issues. As a result, the main source countries and proportions for each component of the programme have changed over time.

In 2002-03, very few asylum seekers were granted protection in Australia, and the vast majority of visa recipients were processed through the offshore component. Five of the top ten countries of birth were in the Africa region (Sudan, Ethiopia, Liberia, Sierra Leone, and Somalia), while (former) Yugoslavia and Croatia also featured.

In 2007-08, the Humanitarian cohort was more geographically balanced, with around one-third coming from Asia, one-third from Africa, and one-third from the Middle East. In 2013-14, almost half of all Humanitarian visas were granted to people originating from Afghanistan and Iraq (both offshore resettlement and onshore asylum seekers). Other major source countries were Myanmar (predominantly through offshore resettlement) and Pakistan (predominantly onshore asylum seekers) (Figure 13).

\section{Temporary migration-a pathway to permanence}

\section{Introduction}

There are three main categories of temporary resident visas available in Australia. Working Holiday Maker (WHM) visas are targeted at young adults interested in having an extended holiday in Australia, combined with periods of short-term work and the opportunity to study. The Subclass 457 visa is a skilled work visa that enables Australian businesses to sponsor employees for up to four years. ${ }^{10}$ Finally, student visas are for people studying full-time in the university, vocational, or schools sectors. ${ }^{11}$

9. At the time of writing (14 March 2014), only two asylum seekers had arrived by boat in the first three months of 2014, as per information from the Operation Sovereign Borders newsroom website, Department of Immigration and Border Protection.

10. The official name of this visa is Temporary Work (Skilled) visa (subclass 457).

11. In addition to these three major categories is a range of other, less commonly used visas, allowing people 
Smith et al.: Developments in Australian migration

\begin{tabular}{|c|c|c|c|}
\hline \multicolumn{4}{|c|}{ 2002-03 Humanitarian Programme 12522 grants } \\
\hline \multicolumn{2}{|c|}{ Offshore Resettlement - 11656 grants } & \multicolumn{2}{|c|}{ Onshore Protection - 866 grants } \\
\hline \multicolumn{4}{|c|}{ Main Categories } \\
\hline Offshore Refugee & 4380 grants & \multirow{2}{*}{ Onshore Refugee } & \multirow{2}{*}{866 grants } \\
\hline Special Humanitarian Programme & 7280 grants & & \\
\hline \multicolumn{4}{|c|}{ Main Regions } \\
\hline Africa & $47 \%$ & Iraq & $14 \%$ \\
\hline Middle East and South West Asia & $37 \%$ & Iran & $9 \%$ \\
\hline Europe & $10 \%$ & Sri Lanka & $8 \%$ \\
\hline \multicolumn{4}{|c|}{ 2007-08 Humanitarian Programme 13014 grants } \\
\hline \multicolumn{2}{|c|}{ Offshore Resettlement - 10799 grants } & \multicolumn{2}{|c|}{ Onshore Protection - 2215 grants } \\
\hline \multicolumn{4}{|c|}{ Main Categories } \\
\hline Offshore Refugee & 6004 grants & \multirow{2}{*}{ Onshore Refugee } & \multirow{2}{*}{1900 grants } \\
\hline Special Humanitarian Programme & 4795 grants & & \\
\hline \multicolumn{4}{|c|}{ Main Regions } \\
\hline Myanmar & $27 \%$ & Sri Lanka & $22 \%$ \\
\hline Iraq & $21 \%$ & PRC & $21 \%$ \\
\hline Afghanistan & $11 \%$ & Iraq & $11 \%$ \\
\hline \multicolumn{4}{|c|}{ 2012-13 Humanitarian Programme 19985 grants } \\
\hline \multicolumn{2}{|c|}{ Offshore Resettlement - 12477 grants } & \multicolumn{2}{|c|}{ Onshore Protection - 7508 grants } \\
\hline \multicolumn{4}{|c|}{ Main Categories } \\
\hline Offshore Refugee & 11,974 grants & \multirow{2}{*}{ Onshore Refugee } & \multirow{2}{*}{7508 grants } \\
\hline Special Humanitarian Programme & 503 grants & & \\
\hline \multicolumn{4}{|c|}{ Main Regions } \\
\hline Iraq & $33 \%$ & Afghanistan & $32 \%$ \\
\hline Afghanistan & $19 \%$ & Iran & $18 \%$ \\
\hline Myanmar & $19 \%$ & Pakistan & $12 \%$ \\
\hline \multicolumn{4}{|c|}{ 2013-14 Humanitarian Programme 13768 grants $^{1}$} \\
\hline \multicolumn{2}{|c|}{ Offshore Resettlement - 11016 grants } & \multicolumn{2}{|c|}{ Onshore Protection - 2752 grants } \\
\hline \multicolumn{4}{|c|}{ Main Categories } \\
\hline Offshore Refugee & 6,501 grants & \multirow{2}{*}{ Onshore Refugee } & \multirow{2}{*}{2752 grants } \\
\hline Special Humanitarian Programme & 4,515 grants & & \\
\hline \multicolumn{4}{|l|}{ Main Regions } \\
\hline Afghanistan & $25 \%$ & Pakistan & $17 \%$ \\
\hline Iraq & $21 \%$ & Egypt & $15 \%$ \\
\hline Myanmar & $17 \%$ & Iran & $14 \%$ \\
\hline
\end{tabular}

\section{Figure 13. Composition of the Humanitarian Programme across different years.}

Source: Population Flows Immigration Aspects (various edns) and Australia's Migration Trends (various edns). Note: Figures officially revised at the end of 2013-14, and therefore may differ from statistics previously published. 1. Includes a small number of visas granted through ministerial intervention counted against the Programme.

into Australia for social, cultural, international relations, training and research purposes, or for undertaking highly specialized short-stay work. 
While there have been many changes in the regulation and policy framework underpinning these temporary residence categories, these types of visas have been in existence for many years; Australia's Working Holiday Maker Programme commenced in 1975 with an agreement between the UK and Australia; the Subclass 457 Programme commenced in 1996; and the provision of education to international students dates back to the time of the Colombo Plan in the late 1950s.

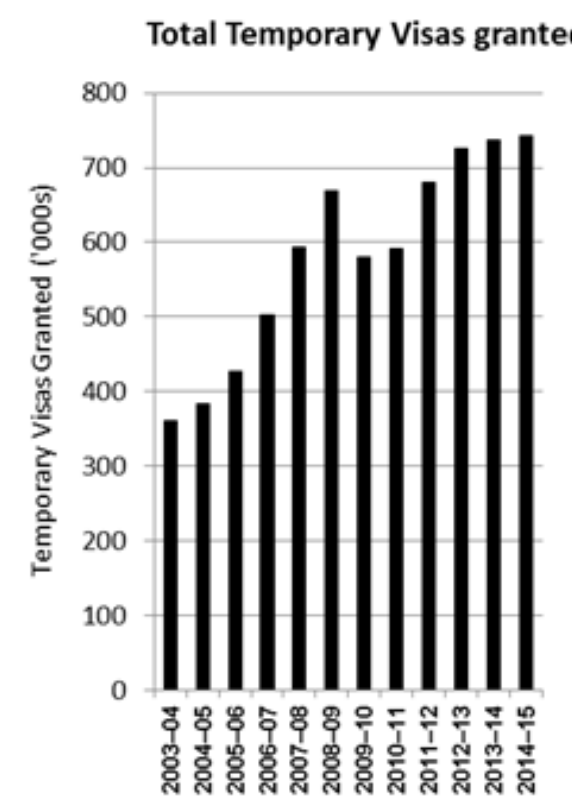

Programme Year

\section{Student Visas granted}

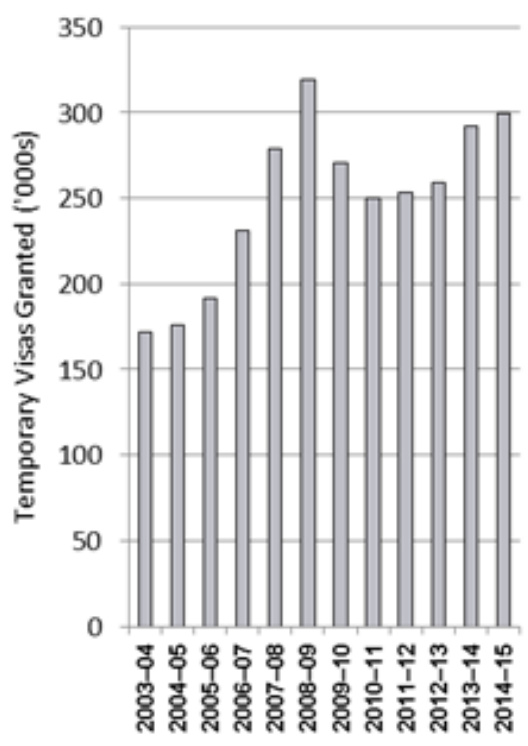

Programme Year
Working Holiday Maker Visas granted

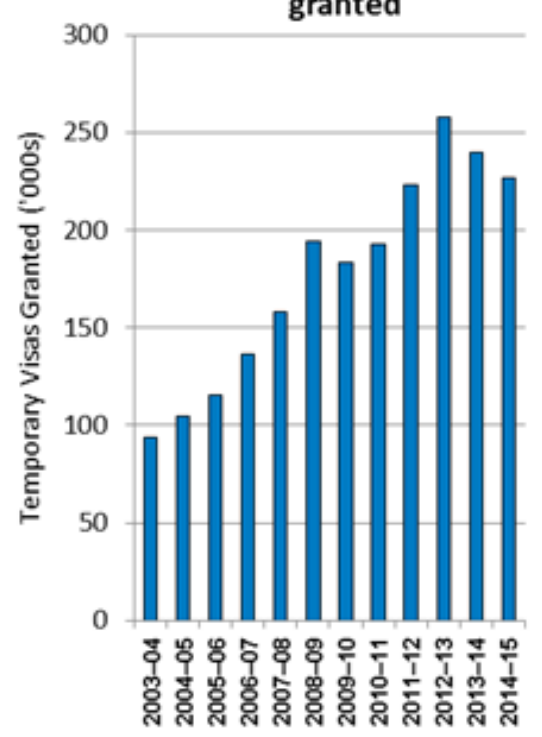

Programme Year

Temporary Work (Skilled) Visas granted

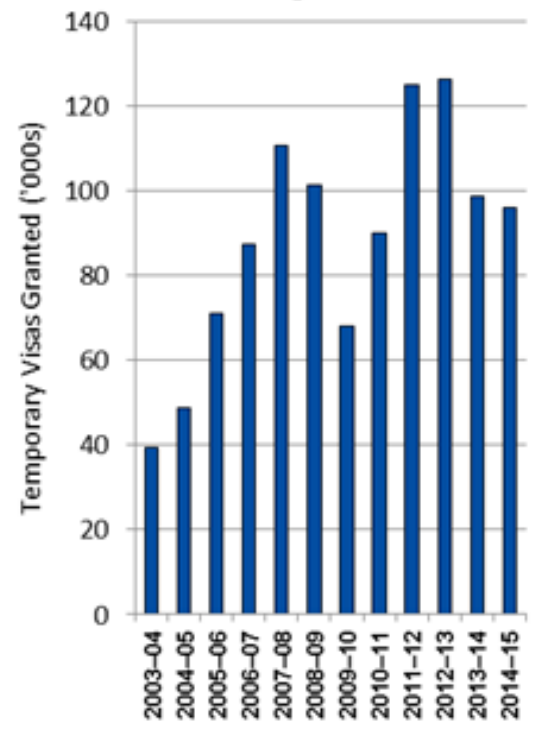

Programme Year

Figure 14. Grants of Temporary visas, 2003-04 to 2014-15.

Source: Department of Immigration and Border Protection, Temporary Entry Statistics. 
All three categories of visa are uncapped, meaning that in most circumstances a visa will be issued to any applicant who meets the requirement of the visa and pays the relevant fee. ${ }^{12}$ This factor, along with other factors such as greater labour mobility, lower travel costs, growth in international education, and the increased presence of migrant networks in Australia, has contributed to strong growth in these visas over the past decade (Figure 14).

Despite this growth, the 2009-10 programme year saw a significant drop for these visa categories and temporary visas more generally. This drop was almost entirely due to a fall in demand (rather than supply) associated with the global financial crisis; for student visas, additional factors included increased competition from other countries, a stronger Australian dollar, student safety, education provider closures, and integrity concerns. In other words, there was no change in the way these types of visas were approved or granted; the smaller grant numbers were almost entirely a result of the smaller pool of applicants.

Since the end of the global financial crisis, WHM and Temporary Work (Skilled) visa grants have increased past their pre-global financial crisis highs. Student visa demand also recovered, but remained at lower levels for longer. Virtually all temporary residence visas come with work permits, thereby helping to meet Australia's labour needs. In practice, this means that holders of subclass 457 visas are sponsored to work full-time in skilled jobs that are difficult to fill domestically. Working Holiday Makers fill an important niche as seasonal workers on Australian farms and in the hospitality sector, and many international students work part-time to help support themselves during their studies.

Aside from the obvious benefit of funding a study or a working holiday, this arrangement also delivers substantial fiscal benefits, as temporary residents are generally required to pay taxes on income earned in Australia but have very limited access to government services. For example, temporary migrants are ineligible for welfare, and unless reciprocal healthcare agreements are in place, they are also unable to access public health services. While most jurisdictions in Australia allow the children of temporary visa holders to attend government schools free of charge, there are exceptions: New South Wales, which charges annual tuition fees of up to $\$ 6,000$ per child, the Australian Capital Territory (up to $\$ 13,900$ per child), and Western Australia ( $\$ 4,000$ per family) (DTWD 2015).

\section{Australia's Student Programme}

With around 260,000 places offered each year to international students, Australia is (after the US and UK) the third-largest provider of education services to international students in 2011 (OECD 2014). In fact, with export earnings of $\$ 17.6$ billion in 2014, international education is Australia's fourth-largest source of export earnings - after iron ore, coal, and natural gas (DFAT 2014).

With such a large and diverse caseload, the risk of people breaching the conditions of their visa is ever-present. To mitigate against this, until March 2014 applicants for student visas were assigned an Assessment Level (AL) of risk between 1 (low) and 5 (high). The level was derived from compliance data that took into account an applicant's country of origin and education credits. In March 2014, the government simplified the AL framework, and now it comprises three levels (AL1 to AL3). Applicants who are part of a cohort that is, based on evidence, deemed to be of greater risk of noncompliance are required to provide a higher level of evidence as part of their migration application.

Following a review of the student visa programme in 2011, the concept of streamlining was introduced in March 2012 at eligible universities, and subsequently extended to eligible non-university

12. A minor exception to this general rule is the annual caps on the number of Work and Holiday (subclass 462) visas issued to applicants from countries such as Chile, Indonesia, Argentina, and Thailand. 
higher education and vocational education and training (VET) providers in 2014 (DIAC 2011b). Under this scenario, applicants are assigned either a streamlined or non-streamlined pathway, based on the institution they plan to attend. Those with a confirmed enrolment at an institution with a good record on immigration compliance (based on an analysis of departmental data) are processed through the streamlined pathway, and will be processed more quickly. Those going through the nonstreamlined pathway continue to follow the Assessment Level process (DIBP 2014c).

In June 2015, the Australian Government announced the introduction of a new simplified international student visa framework to replace both the streamlined visa processing arrangements and the current Assessment Level framework for all international students. The new framework will support the sustainable growth of the international education sector, by enhancing both competitiveness and integrity, while extending streamlined processing to all education sectors and course types. The key changes are: (1) a reduction in the number of student visa subclasses from eight to two; and (2) the introduction of a simplified single immigration risk framework for all international students.

Between the end of the 1990s and through early 2010, there was a strong association between being an international student and obtaining a permanent Skilled Independent visa. This situation was able to flourish because students had the ability to apply for these visas onshore, and because the general skilled migration points test strongly favoured young people who had studied in Australia.

As mentioned earlier, changes to the migration points test between 2010 and 2011 brought this situation to an end, and made the transition to a skilled visa far more difficult for international students. The most notable consequences of these changes were:

1. The end of more than a decade of continued growth in student numbers, with the number of visas issued falling from a peak of 320,000 in 2008-09 to 270,000 one year later. ${ }^{13} \mathrm{~T}$ decline was especially large among vocational students, as growing concerns around visa compliance and fraudulent activity resulted in increased integrity measures for this caseload.

2. An increase in onshore grants of student visas. This was occurring as some students who were already in Australia changed courses, to extend their stay or get a qualification better aligned to a skilled migration outcome.

3. Former students experiencing a more diverse range of permanent migration outcomes. With Skilled Independent visas becoming more difficult to obtain, there has been an increase in partner visas being issued through the Family Reunion Programme, as well as growth in Employer sponsored and State and Territory sponsored visas.

\section{Australia's 457 Programme-filling the gaps}

Businesses can utilise Australia's Subclass 457 Programme in a range of ways. As well as providing a mechanism to bring migrant workers into positions that are difficult to fill, it can be used by overseas businesses seeking to establish a branch in Australia, participate in joint ventures, transfer employees between branches, or fulfil a specific contract.

The subclass 457 visa is designed to meet Australia's short term skill needs, and tends to be sensitive to changes in labour market conditions (Parliament of Australia 2013). This is in contrast to points-tested migration, which takes a longer-term view and takes more account of an applicant's human capital. Underpinning the subclass 457 visa is the Consolidated Sponsored Occupation List (CSOL) - a list of over 700 skilled occupations, or about four times the size of the points-tested Skilled Occupation List (SOL).

13. Visa Reporting, DIBP. 
Following its inception, the programme got off to a slow start, with only 25,786 visas issued in 1995-96 and an average of less than 30,000 visas issued for each of the first five programme years. Over time, however, the ability to facilitate the deployment of a temporary labour force into sectors of the economy experiencing labour shortages has made the subclass 457 Programme increasingly popular with employers. In 2012-13, 126,350 visas were issued under the Programme, which is equivalent to one per cent of the total Australian labour force.

There is also a pathway for skilled workers and their dependents holding a subclass 457 visa to apply for permanent residence. Between 2010 and 2013, more than 120,000 permanent visas were issued to subclass 457 migrants and their families. This equates to approximately 32 per cent ${ }^{14}$ of the number of Subclass 457 visas issued over the same period. Around 92 per cent ${ }^{15}$ of those granted permanent residence received permanent employer-sponsored visas, generally with the same business that had sponsored them temporarily.

With increased growth, there is an increased risk of the scheme being abused and workers being exploited. As a result, the scheme has undergone two rounds of reform since 2009.

The first round of reforms was based on the Deegan Review conducted in 2008; in broad terms, it was designed to ensure that that migrant workers were not being: exploited, used as a substitute for local workers, or used to undercut local wages. Under these new measures, employers were required to match the pay rates of overseas workers with those of Australian workers with the same skills and experience, and to commit to training their own workforces.

The second round of reforms was driven by concerns that the programme was not being used in the way it was intended. Of particular concern was the strong growth in 457 visa activity in industries or parts of Australia that were not experiencing skills shortages. To better align the use of the programme with its original intent, requirements were either strengthened or made clearer. Specific changes included a further increase in the English language requirements, to align it to the standard required for permanent employer sponsorship, requiring the employer to provide greater evidence that the position being filled is genuinely skilled, increasing the range of occupations requiring a skills assessment, requiring regional employers to pay migrant workers at a rate comparable to Australians with similar skills who are working in the same part of Australia, and providing migrant workers more time to find new sponsors if they cease employment.

In addition to these regulatory measures, new legislation was introduced in June 2013 to ensure that employers undertake labour market testing to seek an Australian worker before using the subclass 457 visa programme. The legislation also increased the range of actions the Department could take to sanction sponsors who fail to comply with their obligations, and increased the authority of inspectors to monitor compliance with the programme.

In 2015, legislative change progressed in order to implement the recommendations of the 2014 Independent Review into Integrity in the 457 Programme. This review evaluated programme settings, with a particular focus on bolstering integrity, while maintaining flexibility and responsiveness. In response to this review, the English language requirements have been amended to increase flexibility for 457 visa applicants, and the period during which start-up companies can become approved sponsors has been increased from 12 to 18 months. Further reforms include making it an offence for employers to seek payment for sponsoring an applicant, streamlining of the sponsorship process, and a restructure of the training obligation component of the programme.

14. This figure calculated by summing 457 migrant visa holders and their families who attained permanent residency between 2009-10 and 2012-13, and dividing by total 457 visa holders from 2009-10 to 2012-13.

15. This figure was calculated across programme years 2009-10 to 2014-15. 


\section{Australia's Working Holiday Maker Programme}

Australia's Working Holiday Maker Programme is an important source of supplementary labour for employers in industries that need short-term or seasonal workers, such as the hospitality, agriculture, mining, and construction industries. In addition to meeting labour market needs, the programme encourages cultural exchange between young people and closer ties between arrangement countries. Participants in the programme can stay in Australia for up to 12 months, and those who have worked in regional Australia in the agriculture, mining, or construction sectors may be eligible for an additional 12-month extension.

Growth in this visa category has been strong. In 2014-15, there were 226,812 Working Holiday Maker visas issued - almost triple the number from a decade earlier (93,898 in 2003-04). Growth in the Programme can be attributed to an increase in the number of participating countries, increased awareness of the programme, and the lower costs of international travel. ${ }^{16}$

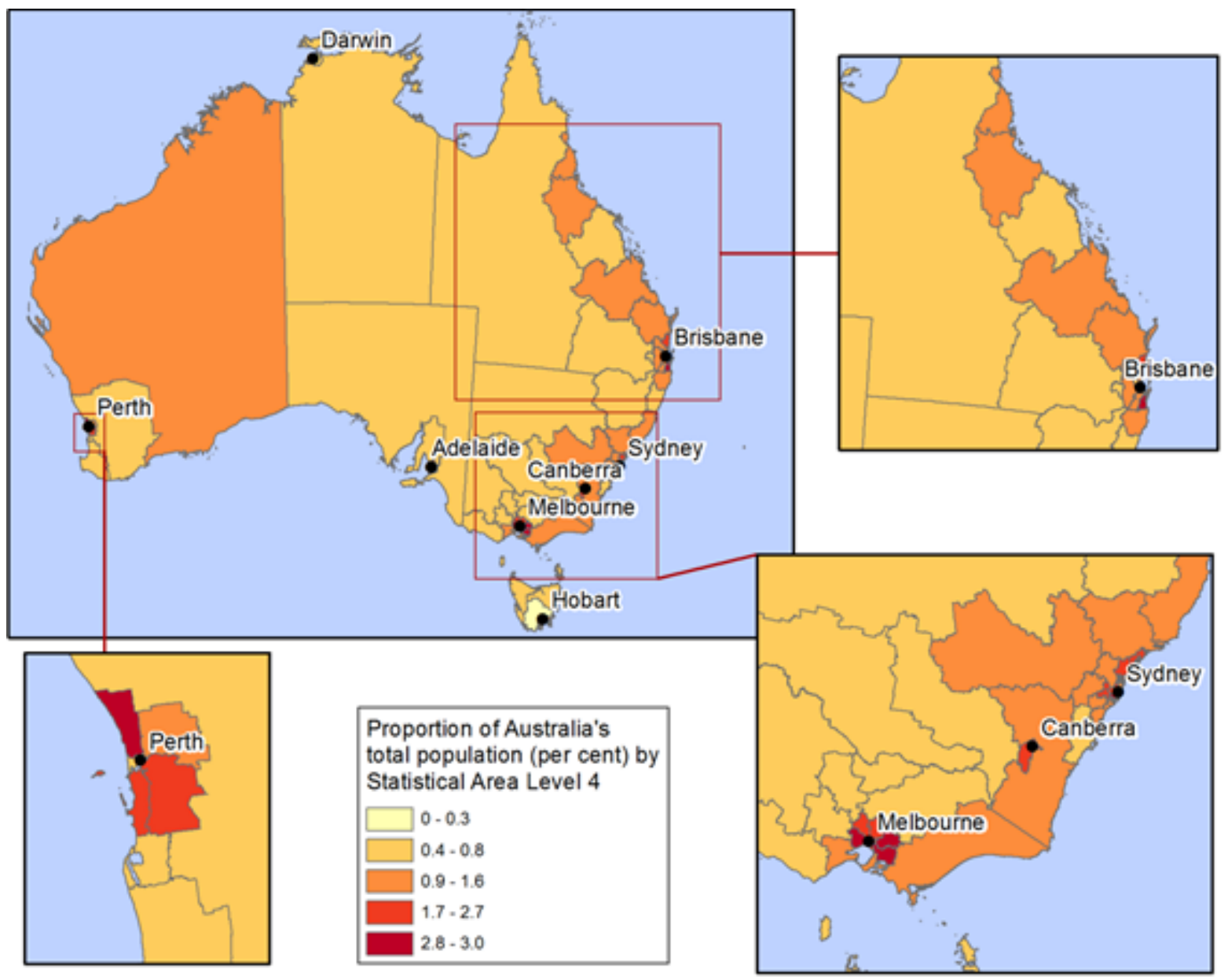

Figure 15. Australia's population distribution by Statistical Area Level 4, ${ }^{17}$ Census 2011 data.

16. At November 2015 there were 32 participating countries. These comprise Belgium, Canada, Cyprus, Denmark, Estonia, Finland, France, Germany, Hong Kong, Ireland, Italy, Japan, Korea, Malta, Netherlands, Norway, Sweden, Taiwan, United Kingdom, Argentina, Bangladesh, Chile, China, Indonesia, Malaysia, Poland, Portugal, Spain, Thailand, Turkey, USA and Uruguay.

17. Statistical Areas Level 4 (SA4s) are designed to reflect one or more whole labour markets for the release of Labour Force Survey data. SA4s are required to have large populations of over 100,000 persons, in order to enable accurate labour force survey data to be generated on each. For this reason, in rural areas SA4s 
Another factor has been the global financial crisis. For instance, between 2008 and 2012, Ireland, a country of less than five million, emerged as a major provider of Working Holiday makers to Australia. It is likely that the high rates of Irish youth unemployment were behind much of this growth. Since then, demand from Ireland has fallen to around 30 per cent.

While working holidaymakers are an important source of supplementary labour, unlike other work visas, the scheme is not targeted towards any occupation (through the SOL or CSOL) or region of Australia in particular. Therefore, according to a 2008 departmental survey, people issued these visas tend to be employed in lower-skilled jobs in the hospitality and agriculture industries (Tan et al. 2009).

\section{Regional dispersal of migrants}

Thus far in this paper, we have looked at the policies and programmes administered by the Department of Immigration and Border Protection that control the flow of people coming into Australia. In this final section, we examine the dispersal of these migrants after they enter Australia, including migrant settlement, labour market integration, social cohesion, provision of services, and housing availability.

Australia is one of the world's most urbanized countries. Some 62 per cent of our population lives in one of the five mainland state capitals (ABS 2011). Beyond these major cities, there are also other significant population centres on Australia's eastern seaboard (Figure 15). By comparison, Australia's overseas-born population is even more highly urbanized, and is concentrated in Melbourne and Sydney (Figure 16); these, Australia's two largest cities, are home to 52 per cent of migrants (ABS 2011), compared to 40 per cent of the overall Australian population.

Such an uneven population distribution, compounded with very large distances, means that access to services, employment opportunities, and lifestyle choices is limited for those migrants who happen to live in regional areas. In order to build and maintain sustainable communities outside the major cities, and to address skill shortages within regional and remote parts of Australia, the Australian Government offers various incentives to certain occupations, in order to entice workers to remain within these regional areas. These can take the form of targeted incentives, such as regional scholarships allocated to teachers and medical professionals through the Australian Government's rural health workforce strategy incentive programmes (Rural Health 2014) and the New South Wales State Government's fast-track teaching development options (NSW Government 2014).

There are also policy interventions, such as Australia's Regional Sponsored Migration Scheme. As already mentioned, this scheme offers a slightly easier skilled migration pathway for employersponsored migrants who are willing to settle in regional Australia and work for a regionally based business for at least two years.

To fill seasonal or temporary employment opportunities, the Australian Government has developed temporary migration policies in order to entice overseas workers into regional areas. The ongoing Seasonal Worker Programme, which replaced the Pacific Seasonal Worker Pilot Scheme, is one example. The programme builds on the pilot's economic development objectives for the Pacific and Timor-Leste, while assisting Australian employers who cannot source local labour in selected industries.

generally represent aggregations of multiple small labour markets with socioeconomic connections or similar industry characteristics. Large regional city labour markets (150,000 people) are generally defined by a single SA4. Within major metropolitan labour markets, SA4s represent sub-labour markets (Glossary, Census Geographic Areas, www.abs.gov.au). 


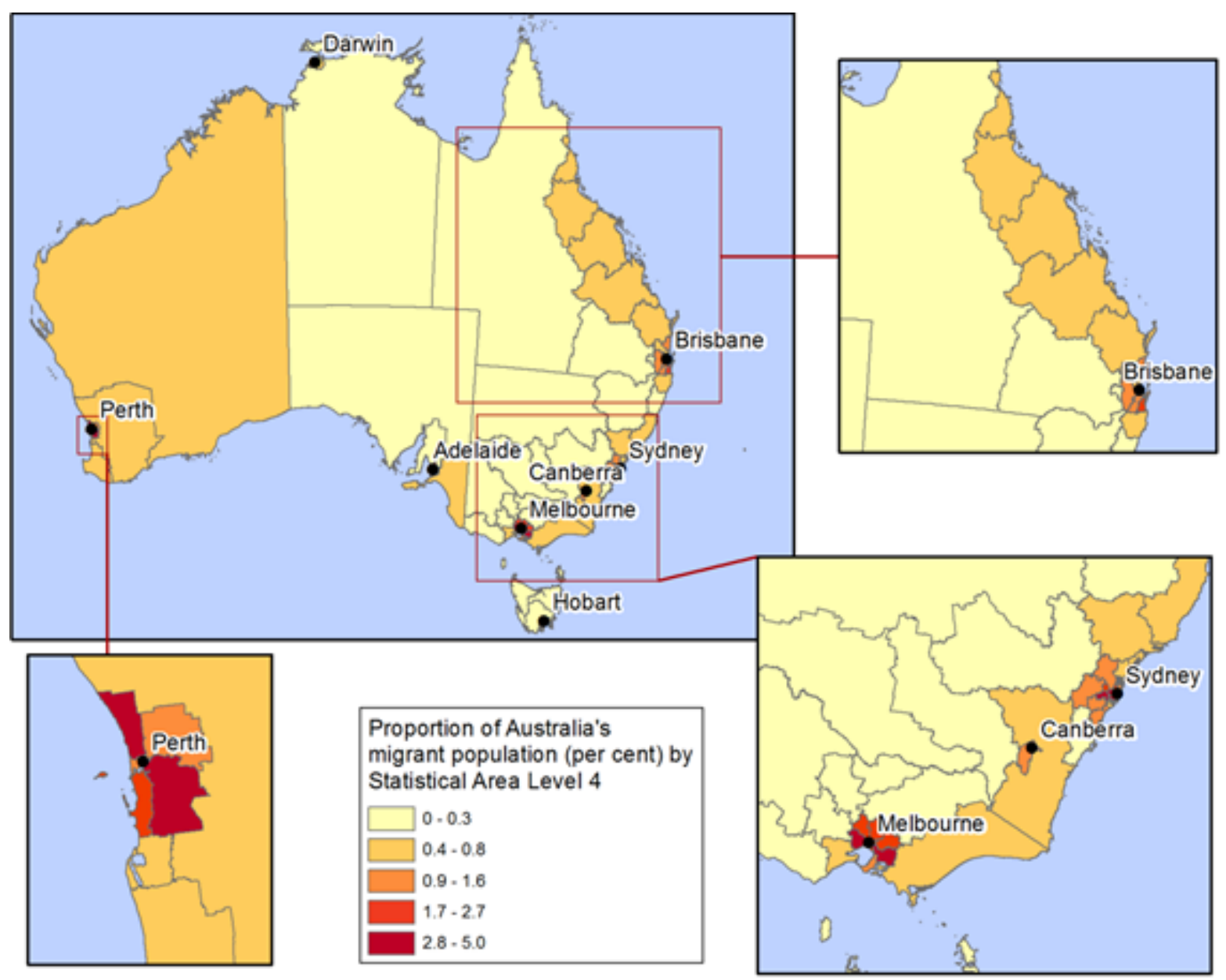

Figure 16. Australia's migrant population distribution by Statistical Area Level 4, Census data 2011.

For example, this programme allows horticultural businesses to recruit seasonal workers from Papua New Guinea as well as Kiribati, Nauru, Samoa, Solomon Islands, Timor-Leste, Tonga, Tuvalu, and Vanuatu. The programme also includes a small-scale three-year trial with the accommodation, aquaculture, cane, and cotton sectors in selected regions. The programme is demand-driven, with the number of visa places capped at 12,000 over four years (2012-16): 10,450 visas open to the horticulture industry nationally over four years, and 1,550 visas for the small-scale trial in selected regions, to end in June 2015. As at 30 June 2013, just under 1,500 grants had been issued under the Pacific Seasonal Worker Programme (DIBP 2014g).

While Australia's Humanitarian Settlement Service aims to locate refugee and humanitarian entrants with family or friends close to metropolitan areas, the possible rural background of many humanitarian entrants provides opportunities to foster regional engagement and development. This approach is supported by local community networks, and enables new humanitarian entrants to feel part of a community and contribute to the Australian economy (DSS 2013). More than 15,500 vulnerable women and their dependents have been resettled in Australia under this service since it was introduced in 1989.

Australia's Working Holiday Maker Programme, which currently issues in excess of one-quarter of a million visas per year, is a significant provider of temporary labour to regional Australia, particularly in the highly seasonal agricultural sector. A 2008 survey of working holidaymakers showed that 41 per cent of jobs held were in regional areas, and that farmhands were the single largest job 
classification, accounting for more than one-quarter of all jobs held (Tan et al. 2009). Government initiatives such as the harvest trail website, and informal networks, are an important facilitator in this respect, helping direct this pool of mostly unskilled labour to where the jobs are.

Working against these efforts to bring migrants into different parts of Australia is a high propensity for recently arrived permanent migrants to move considerable distances from where they first settled. These moves are influenced by lifestyle considerations, including access to family and friends, cultural and lifestyle choices, and employment opportunities. Data from the Australian Census and Migrants Integrated Dataset for 2011 (ABS 2014) provide additional insight into this issue.

Box 1 - International and Internal Migration by State and Territory.

Location of overseas migrants arriving 2006 to 2011
\begin{tabular}{|l|r|r|r|r|r|r|r|r|r||}
\hline & NSW & VIC & QLD & SA & WA & TAS & NT & ACT & TOTAL \\
\hline Family stream & \multicolumn{7}{|c|}{ Thare of Family stream (\%) } \\
\hline Capital City & 35.9 & 24.5 & 8.5 & 4.2 & 9.6 & 0.4 & 0.6 & 1.6 & 85.4 \\
\hline Rest of State/Territory & 4.2 & 2.2 & 6.0 & 0.4 & 1.2 & 0.4 & 0.2 & 0.0 & 14.6 \\
\hline Skill stream & & & & \multicolumn{7}{|c|}{ Share of Skill stream (\%) } & & \\
\hline Capital City & 27.3 & 24.7 & 9.8 & 6.8 & 15.6 & 0.4 & 0.6 & 1.6 & 86.9 \\
\hline Rest of State/Territory & 2.6 & 1.6 & 6.4 & 0.4 & 1.6 & 0.3 & 0.2 & 0.0 & 13.1 \\
\hline
\end{tabular}

Net interstate migration of overseas migrants: 2006 to 2011

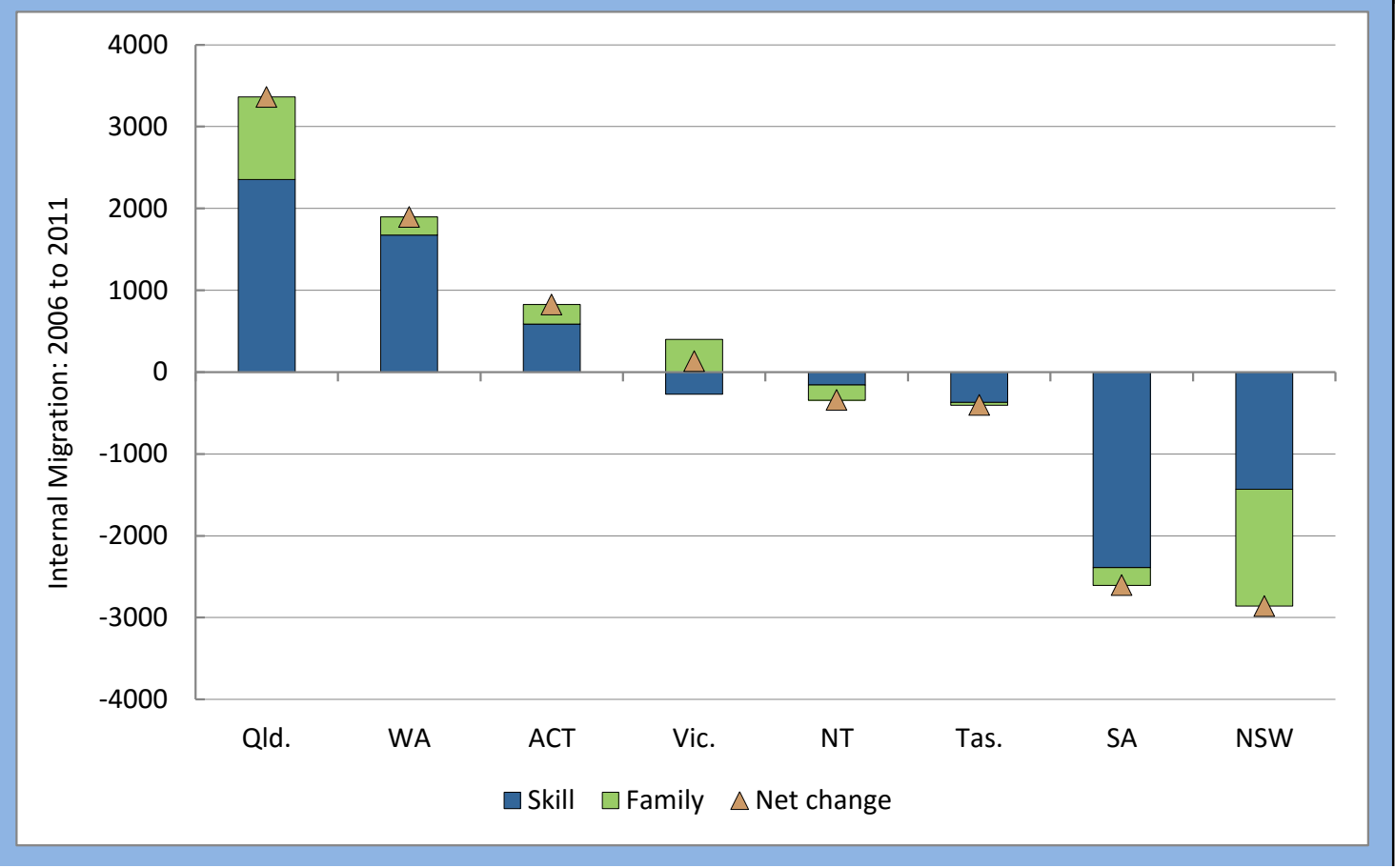



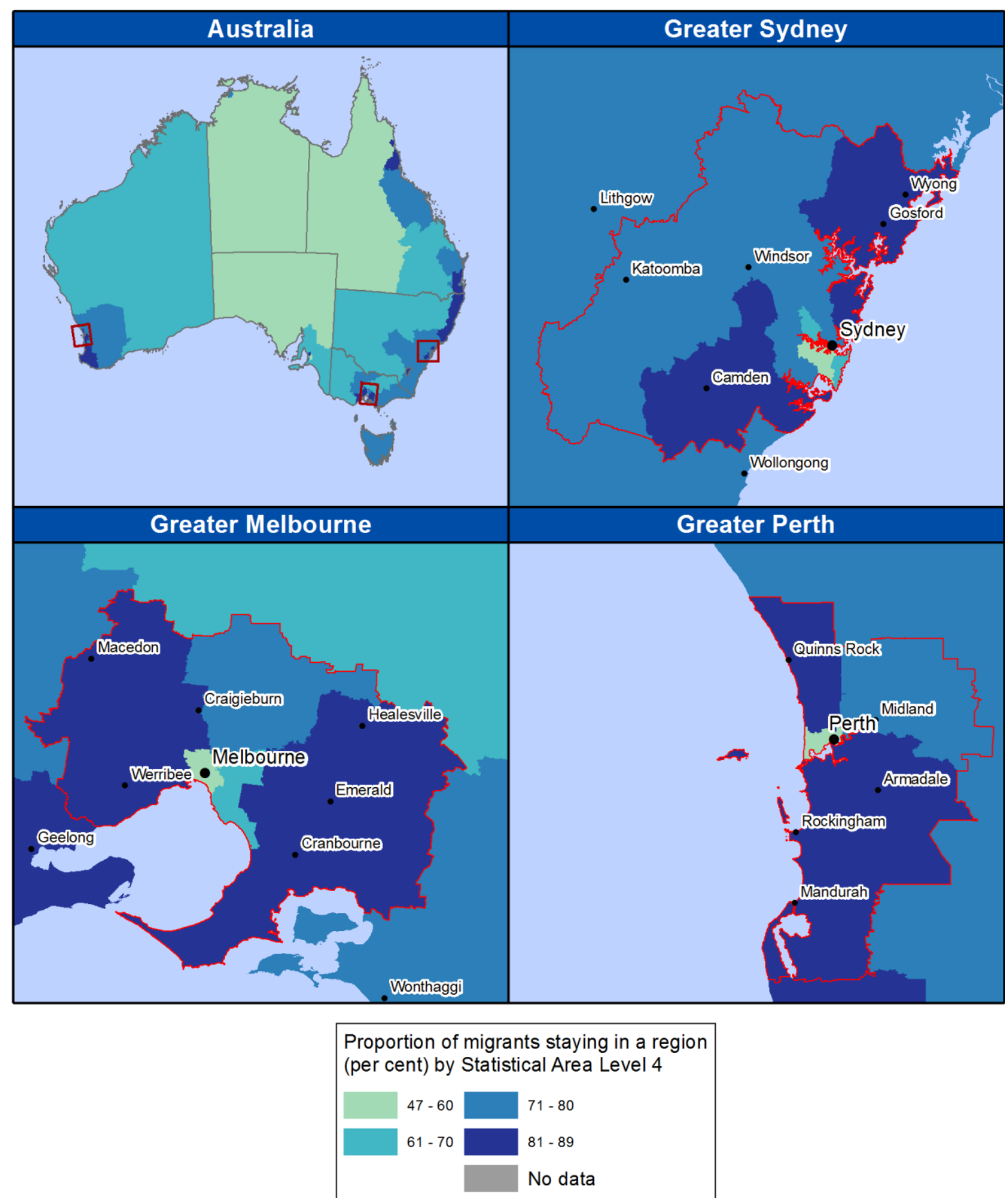

Figure 17. Proportion of migrants staying in a region by Statistical Area Level 4. Source: Census data 2006 to 2011.

The first part of Box 1 shows that newly arrived migrants coming to Australia between 2006 and 2011 were most likely to locate within New South Wales and Victoria, with Greater Sydney being the most popular location for Family stream migrants and Skill stream migrants. South Australia and Western Australia stand out, as they have a much larger share of the skill cohort compared to their 
share of the family cohort. By virtue of its more decentralized population, Queensland was the only jurisdiction to have comparable numbers of migrants living in and outside the state capital. For Australia overall, capital city migrants outnumbered non-capital city migrants by more than six to one.

With the passage of time, there has been significant interstate movement. This is shown in the second half of Box 1, which reports on interstate migration between 2006 and 2011. Using this measure, Queensland and Western Australia, with their stronger labour markets, were the main beneficiaries of this movement, largely at the expense of New South Wales and South Australia.

From a regional perspective, the ability to retain migrants within an area is especially challenging. Large areas of regional Australia have lost one-third or more of their migrants to other parts of Australia, or overseas, in just a five-year period-in other words, more than one-third of the overseas-born population that was counted in the 2006 Census of Population and Housing was elsewhere at the time of the 2011 Census. The only exceptions to this general rule were the more densely populated parts of South Eastern and South Western Australia that are relatively close to major cities (Figure 17), and those regional areas within Queensland that have significant mining investment. This implies that access to the amenities in major urban areas plus access to strong job markets are an important enabler of migrant retention.

\section{Acknowledgements}

The authors would like to acknowledge the many people from the Department of Immigration and Border Protection who contributed information and data to help in the preparation of this paper.

We would also like to acknowledge advice from within the department of Marianne Gomba, Janice Wykes, and Rachael Spalding, who reviewed the report, provided important additions, and were crucial in shaping the final product.

The late Professor Graeme Hugo was responsible for conceiving this report. We are therefore grateful for his early support and advice, plus the very practical support provided by Professor Peter McDonald, who helped see this paper through to its conclusion.

\section{References}

ABS (Australian Bureau of Statistics). 2011. Census of Population and Housing Tablebuilder data. Canberra: Australian Government.

—. 2014. Australian Census Migrant Integrated Dataset. Canberra: Australian Government.

Cully, M. 2011. Skilled Migration Policy: Recent Australian Reforms. Migration Policy Practice 1(1):4-7.

Customs (Australia Department of Customs). 2014. Operation Sovereign Borders Home Page. Canberra: Australian Government. http://www.customs.gov.au/site/operation-sovereign-borders. asp (retrieved April 30, 2014).

DFAT (Australia Department of Foreign Affairs and Trade). 2014. Australia's trade in goods and services 2014. Canberra: Australian Government. http://dfat.gov.au/about-us/publications/ trade-investment/australias-trade-in-goods-and-services/Pages/australias-trade-in-goods-andservices-2014.aspx\# exports (retrieved September 16, 2015).

DIAC (Australia Department of Immigration and Citizenship). 2009a. Population Flows: Immigration Aspects 2008-09. Canberra: Australian Government. 
. 2011a. Points Test for Certain Skilled Migration Visas, 1 July 2011. Canberra: Australian Government. http://www.immi.gov.au (retrieved June 2011).

. 2011b. Strategic Review of the Student Visa Program, 30 June 2011. Canberra: Australian Government. https://www.border.gov.au/ReportsandPublications/Documents/reviews-andinquiries/2011-knight-review.pdf (retrieved April 30, 2014).

2012. Innovation Points Test for the Business Innovation and Investment Program, August 2012. Canberra: Australian Government.

—. 2013a. Skill Select Booklet 11, July 2013. Canberra: Australian Government.

_. 2013b. Temporary entrants and New Zealand citizens in Australia, December 2013. Canberra: Australian Government. https://www.border.gov.au/ReportsandPublications/Documents/ statistics/temp-entrants-newzealand-dec13.pdf (retrieved April 30, 2014).

DIBP (Australia Department of Immigration and Border Protection). 2014a. Business Migration. Fact Sheet 27. Canberra: Australian Government. http:/ /www.border.gov.au/about/corporate/ information/fact-sheets/27business (retrieved April 30, 2014; September 11, 2015).

2. 2014b. Australia's Migration Trends (2013-14). Canberra: Australian Government. http:// www.border.gov.au/about/reports-publications/research-statistics/statistics/live-in-australia/ migration-programme/trends-2013-14 (retrieved September 16, 2015).

- 2014c. Streamlined Student Visa Processing. Canberra: Australian Government. http://www. border.gov.au/Trav/Stud/Stre (retrieved September 11, 2015).

- 2014d. Filling the Gaps: Findings from a Survey of Subclass 457 Visa Holders and Their Employers. Canberra: Australian Government.

2014e. Key facts about immigration. Fact Sheet 2. Canberra: Australian Government. http:// www.border.gov.au/about/corporate/information/fact-sheets/02key (retrieved April 30, 2014).

. 2014f. State-specific regional migration. Fact Sheet 26. Canberra: Australian Government. http://www.border.gov.au/about/corporate/information/fact-sheets/26state (retrieved September 11, 2015).

- 2014g. Australia's Migration Trends 2012-13. Canberra: Australian Government. http://www. border.gov.au/about/reports-publications/research-statistics/statistics/live-in-australia/migrationprogramme/trends-2012-13 (retrieved April 30, 2014).

- 2015. Designated area migration agreements (DAMAs), August 2014. Canberra: Australian Government. http://www.border.gov.au/WorkinginAustralia/Documents/dama.pdf (retrieved September 16, 2015).

DSS (Australia Department of Social Services). 2013. Getting Settled: Women Refugees in Australia. Canberra: Australian Government. https://www.dss.gov.au/sites/default/files/ documents/01_2014/sc_update_women_at_risk.pdf (retrieved April 30, 2014).

Dutton, P. 2015. Syrian Humanitarian Crisis. Media Release of the Minister for Immigration and Border Protection. Canberra: Australian Government. http://www.minister.border.gov.au/ peterdutton/2015/Pages/syrian-humanitarian-crisis.aspx (retrieved September 17, 2015). 
DTWD (Department of Training and Workforce Development). 2015. Dependants of 457 visa holders. Perth WA: Government of Western Australia. http://www.eti.wa.edu.au/your-study-options/studyat-school/dependants-of-457-visa-holders (retrieved September 11, 2015).

Houston, A., P. Aristotle, and M. L'Estrange. 2012. Report of the Expert Panel on Asylum Seekers, August 2012. Canberra: Australian Government. http://expertpanelonasylumseekedpmc.gov.au (retrieved April 30, 2014).

Markus, A. 2013. Scanlon Foundation Surveys: Mapping Social Cohesion Survey 2013. Victoria (Australia): Monash University. http://scanlonfoundation.org.au/wp-content/uploads/2014/07/ mapping-social-cohesion-national-report-2013.pdf (retrieved April 30, 2014).

NSW Government. 2014. Teach Rural Scholarships. Sydney: New South Wales Government, Department of Education and Communities. http://www.dec.nsw.gov.au/about-us/careers-centre/ school-careers/teaching/our-programs-and-initiatives/teach-rural-scholarships (retrieved February 18, 2014).

OECD (Organisation for Economic Cooperation and Development). 2014. Stat Extracts, data for 2011. http://www.oecd.org/Index.aspx?DataSetCode=RFOREIGN (retrieved May 5, 2014).

Parliament of Australia. 2013. The subclass 457 Visa: A Quick Guide, 11 November 2013. Canberra: Parliament of Australia. http://www.aph.gov.au/About_Parliament/Parliamentary_Departments/ Parliamentary_Library/pubs/rp/rp1314/QG/Subclass457Visa (retrieved April 30, 2014).

Price, C. 1999. Australian population: Ethnic origins. People and Place 7(4):12-16.

Rural Health (Rural Health Australia). 2014. Rural Health Workforce Strategy (RHWS) Incentive Programs. Victoria (Australia): Australian Government, Rural Health Workforce Australia. http:// www.ruralhealthaustralia.gov.au/internet/rha/publishing.nsf/Content/RHWS_incentive_programs (retrieved February 18, 2014).

Tan, Y., S. Richardson, L. Lester, T. Bai, and L. Sun. 2009. Evaluation of Australia's Working Holiday Maker (WHM) Program. Canberra: Australian Government, Department of Immigration and Citizenship. 